TOMASZ OPALIŃSKI

https://orcid.org/0000-0002-2661-1921

Akademia Finansów i Biznesu Vistula

filia: Akademia im. Aleksandra Gieysztora

\title{
CHŁOPSKIE PRAWA DO ZIEMI I UDZIAŁ CHŁOPÓW W OBROCIE NIERUCHOMOŚCIAMI W KSIESTWIE WARSZAWSKIM W ŚWIETLE AKT NOTARIALNYCH (NA PRZYKŁADZIE POWIATU KONIŃSKIEGO)
}

\begin{abstract}
Zarys treści: Artykuł przedstawia wyniki analizy umów kupna-sprzedaży nieruchomości chłopskich zawartych w okresie Księstwa Warszawskiego na terenie powiatu konińskiego. Badania zostały oparte na materiale archiwalnym w postaci aktów notarialnych sporządzonych przez notariusza konińskiego Wilhelma Sztandkego oraz urzędników konińskiego sądu pokoju. Dokumentacja ta przechowywana jest w konińskim oddziale Archiwum Państwowego w Poznaniu. Analizie zostały poddane takie elementy jak: rodzaj i powierzchnia sprzedawanych nieruchomości, warunki dyktowane w umowach chłopom przez szlachtę (cena, wysokość powinności, konsens, laudemium), swoboda dalszego obrotu zakupionymi nieruchomościami przez chłopów, udział chłopów w obrocie na tle pozostałych stanów oraz zasoby finansowe chłopów w świetle dokonanych transakcji.
\end{abstract}

The content outline: The article discusses the outcome of the analysis of purchase/sale agreements concerning peasant-owned land properties concluded in the Konin County during the existence of the Duchy of Warsaw. The research is based on archival materials in the form of notarial needs drawn up by Konin Notary Wilhelm Sztandke and clerks of the Konin Justice of the Peace. The documents are stored in the Konin branch of the State Archives in Poznań. The analysis comprises the following aspects: the type and area of sold properties, conditions imposed on peasants by nobility (price, fees, consensus, laudemium), freedom of trading in properties purchased by peasants, participation of peasants in property trade in comparison to other classes, and financial resources of peasants in view of the finalized transactions.

Słowa kluczowe: Księstwo Warszawskie, akta notarialne, chłopi, grunty, własność podzielona, czynsz, pańszczyzna 
Keywords: Duchy of Warsaw, notarial deeds, peasants, land property, divided dominium, quit rent, serfdom

Jednym z postanowień traktatu pokojowego w Tylży (7 i 9 VII 1807 r.) kończącego wojnę Napoleona z IV koalicją antyfrancuską było utworzenie Księstwa Warszawskiego.

22 VII 1807 r. cesarz Francuzów nadał nowemu państwu konstytucję, która m.in. zniosła poddaństwo oraz jako prawo cywilne ustanowiła nowoczesną kodyfikację - Kodeks Napoleona.

W związku z tym dla szlacheckich właścicieli gruntów najbardziej palącym problemem stała się kwestia uprawnień chłopów do użytkowanych przez nich gospodarstw ${ }^{1}$. W kraju o dominujacej roli rolnictwa w gospodarce prawa poszczególnych stanów do ziemi były podstawowym zagadnieniem społecznym i ekonomicznym. Kwestię tę dla dóbr prywatnych rozwiązał dekret dopełniający konstytucję z 21 XII 1807 r., nazywany $\mathrm{w}$ historiografii dekretem grudniowym ${ }^{2}$. Przyznał on pełna własność ziemi dotychczasowym panom gruntowym ${ }^{3}$.

Spod działania tego prawa wyłączona została grupa chłopów dysponująca wcześniej podpisanymi kontraktami z dworem, opartymi na różnych formach gruntowej własności podzielonej (tzw. lepszego prawa do ziemi ${ }^{4}$ ), wpisywanymi za czasów pruskich do ksiag hipotecznych ${ }^{5}$. Gospodarstwa takie dość licznie występowały na terenie Wielkopolski ${ }^{6}$.

Wejście w życie Kodeksu Napoleona, co nastapiło 1 V 1808 r., nie zahamowało procesu zawierania nowych kontraktów opartych na

${ }^{1}$ Wyrazicielem obaw stanu szlacheckiego był m.in. Feliks Łubieński; H. Grynwaser, Kwestia agrarna $i$ ruch włościan $w$ Królestwie Polskim w pierwszej połowie XIX wieku, w: tenże, Pisma, t. 2, Wrocław 1951, s. 37.

${ }^{2}$ Dziennik Praw Księstwa Warszawskiego, t. 1, s. 10-12.

${ }^{3}$ B. Leśnodorski, Elementy feudalne $i$ burżuazyjne $w$ ustroju i prawie Księstwa Warszawskiego, CPH, t. 3, 1951, s. 311.

${ }^{4}$ Tzw. lepsze prawo do ziemi charakteryzowało się pewnością użytkowania gruntu bez ograniczeń czasowych lub długoterminowo, możliwością dysponowania nim po spełnieniu określonych warunków oraz dominacją renty pieniężnej nad odrobkową. Piszę o tym szerzej w dalszej części artykułu.

5 T. Mencel, Chłopi w wyborach do sejmu Księstwa Warszawskiego, w: Wiek XIX. Prace ofiarowane Stefanowi Kieniewiczowi w 60. rocznicę urodzin, red. B. Grochulska, B. Leśnodorski, A. Zahorski, Warszawa 1967, s. 111; Tenże, Zniesienie poddaństwa $w$ Księstwie Warszawskim na tle porównawczym, „Acta Universitatis Lodziensis. Folia Historica" 13, 1983, s. 29-30.

${ }^{6}$ S. Borowski, Rozwarstwienie wsi wielkopolskiej w latach 1807-1914. Studium statystyczne nad społecznymi i ekonomicznymi nastepstwami wtaczenia wsi $w$ orbite rynku, Poznań 1962, s. 34-35. 
zasadach własności podzielonej ani obrotu gruntami dysponującymi takimi prawami?

Piśmiennictwo dotyczące chłopskich praw do ziemi, funkcjonujących w nowych realiach wprowadzonych przez ustawodawstwo Księstwa, jest obszerne i można tu przytoczyć tylko kilka istotniejszych pozycji, gdzie znajdują się dalsze wskazówki bibliograficzne ${ }^{8}$. W pracach tych autorzy skupiali się głównie na aspektach normatywnych oraz kreślili ogólny obraz sytuacji stanu chłopskiego po zaistniałych przekształceniach ustrojowych ${ }^{9}$. Brakuje natomiast opracowań, które bazując na analizie źródeł wytworzonych przez notariat, w sposób szczegółowy, dla mniejszych obszarów, przedstawiałyby różne aspekty chłopskich uprawnień do gruntów, uczestnictwo chłopów w obrocie nieruchomościami czy zasoby pieniężne przedstawicieli tego stanu w świetle zarejestrowanych transakcji ${ }^{10}$. Wymieniony wyżej rodzaj dokumentacji stanowi podstawowe źródło do badań nad własnością chłopską w Księstwie Warszawskim ${ }^{11}$.

Niniejszym artykułem chciałbym częściowo wypełnić tę lukę. Dotyczy on sytuacji na obszarze powiatu konińskiego w departamencie kaliskim (wschodnia Wielkopolska) w latach 1808-1815, a jego podstawę stanowią spisane w przywołanym okresie akty notarialne.

Celem opracowania jest znalezienie odpowiedzi na pytania: o sposób kształtowania się form chłopskiej własności użytkowej (rodzaj i powierzchnia nieruchomości, wymagane powinności oraz ograniczenia),

${ }^{7}$ W. Wójcikiewicz, Prawo hipoteczne Królestwa Polskiego, Wrocław-Warszawa-Kraków 1967, s. 42.

${ }^{8}$ Zob. W. Grabski, Historya Towarzystwa Rolniczego 1858-1861 r., t. 1, Warszawa 1904, s. 1-36; H. Grynwaser, dz. cyt., s. 7-50; W. Sobociński, Historia ustroju i prawa Księstwa Warszawskiego, Torun 1964 (Roczniki Towarzystwa Naukowego w Toruniu, 70, 1), s. 67-77; B. Grochulska, Księstwo Warszawskie, Warszawa 1966, s. 83-93; T. Mencel, Zniesienie poddaństwa...; Z. Stankiewicz, Szlachta wobec zniesienia poddaństwa w Księstwie Warszawskim, „Acta Universitatis Lodziensis. Folia Historica” 13, 1983, s. 43-71; J. Czubaty, Księstwo Warszawskie (1807-1815), Warszawa 2011, s. $321-327$.

9 Więcej szczegółów na temat powinności oraz różnych form posiadania ziemi przez chłopów przyniosły m.in. prace S. Borowskiego i T. Mencla; zob. S. Borowski, Ksztattowanie się rolniczego rynku pracy $w$ Wielkopolsce $w$ okresie wielkich reform agrarnych 1807-1860, Poznań 1963, s. 22-91; T. Mencel, Chtopska własność i posiadanie ziemi przed uwłaszczeniem w Królestwie Polskim, RDSG, t. 48, 1987, s. 53-77.

${ }^{10}$ Można przytoczyć przykłady wąskiego wykorzystania akt notarialnych jako źródeł uzupełniających, ilustrujących pewne procesy; H. Szymańska, Niektóre problemy chłopskich praw do ziemi w Królestwie Polskim w latach 1815-1864, CPH, t. 13, nr 1, 1961, s. 58 .

11 J. Mazurkiewicz, Znaczenie akt notarialnych dla badań nad własnościa w Księstwie Warszawskim i Królestwie Polskim, „Annales Universitatis Mariae Curie-Skłodowska. Sectio F, Nauki Filozoficzne i Humanistyczne” 20, 1965, nr 7, s. 120. 
zakres realizacji przez chłopów zawartych w kontraktach warunków (swoboda obrotu), obecność form własności chłopskiej wykazujących cechy własności pełnej bądź zbliżające się do takiej ${ }^{12}$, charakter udziału chłopów w obrocie nieruchomościami na tle pozostałych stanów oraz ich zasoby finansowe w świetle kwot angażowanych we wspomniany wyżej obrót. Główny nacisk został położony na zbadanie realnego wymiaru powyższych zagadnień, co pomoże lepiej określić pozycję ekonomiczna stanu chłopskiego w Wielkopolsce w momencie istotnych zmian ustrojowych wprowadzanych przez ustawodawstwo Księstwa oraz u progu przechodzenia do gospodarki kapitalistycznej w rolnictwie.

Podstawę źródłową niniejszego artykułu stanowi dokumentacja rękopiśmienna zgromadzona $\mathrm{w}$ dwóch zespołach archiwalnych przechowywanych przez koniński oddział Archiwum Państwowego w Poznaniu.

W pierwszym z nich (Są Pokoju Powiatu Konińskiego) zgromadzono dla okresu od 1808 do połowy 1810 r. 262 akty dobrowolnych czynności (spraw cywilnych niespornych), z których 38 dotyczyło transakcji kupna-sprzedaży różnych nieruchomości. W przywołanych latach dla powiatu konińskiego nie było ustanowionego notariusza i w jego zastępstwie akty dobrej woli przyjmowali urzędnicy sądu pokoju w osobach pisarza lub podsędka. Sytuacja ta zmieniła się w połowie 1810 r., gdy funkcję notariusza w Koninie obją Wilhelm Sztandke. Drugi z badanych zespołów obejmuje dokumentację wytworzona w jego kancelarii w latach 1810-1822 (Akta notariusza Wilhelma Sztandke w Koninie). Kwerendą objęto akta powstałe tam do czerwca 1815 r. włącznie (871 aktów, z czego 188 dotyczących kupna-sprzedaży nieruchomości), czyli do końca istnienia Księstwa Warszawskiego.

Wszystkie dokumenty z kancelarii Sztandkego miały numery i dodatkowo zostały wpisane do zachowanego repertorium. Można więc domniemywać, że mamy do czynienia z całością materiału aktowego wytworzonego przez konińskiego notariusza, co znacznie podnosi wartość badanego zespołu. Nieco gorzej przedstawia się powyższa kwestia jeżeli chodzi o akta spisane przez urzędników sądu pokoju. Przede wszystkim brak w tym przypadku repertorium.

Łącznie analizie poddanych zostało 226 kontraktów kupna-sprzedaży różnych nieruchomości (na 1133 dokumenty zachowane dla badanego okresu w obu kancelariach - 20\%). Chłopi jako co najmniej jedna ze stron uczestniczyli w $96 \mathrm{z}$ nich.

$\mathrm{Na}$ terenach wiejskich przedmiotem obrotu były ziemie rolne, z zabudowaniami lub bez, oraz całe wsie bądź ich części. W miastach kupowano

\footnotetext{
${ }^{12}$ Postulat takich badań pojawił się już kilka dekad temu; tamże, s. 120-121.
} 
i sprzedawano same grunty (place pod budowę oraz ziemie uprawne, takie jak łąki, role czy ogrody) oraz działki ze stojącymi na nich zabudowaniami. Nieruchomości te w zdecydowanej większości znajdowały na terenie powiatu konińskiego ${ }^{13}$.

Wzięcie pod uwagę wszystkich transakcji kupna-sprzedaży nieruchomości pozwoliło uchwycić inwestycje chłopskie na tle analogicznych działań dokonywanych przez pozostałe stany.

Z analizy zostały wyłączone 42 kontrakty krótkoterminowej (kilkuletniej) dzierżawy gruntów i budynków oraz 25 działów spadkowych.

Dokumentacja powstała w powiecie konińskim została wybrana do analizy z racji jego położenia na terenie Wielkopolski. Rokowało to odnalezieniem wymiernej liczby umów zawartych przez ludność chłopska, ponieważ już w okresie przedrozbiorowym znaczna część chłopów gospodarowała tam na podstawie pisemnych kontraktów z dworem ${ }^{14}$. Akta notariatu konińskiego dotyczace kupna-sprzedaży nieruchomości sa reprezentatywne dla tego typu procesów zachodzących na obszarze Wielkopolski.

Notariusze w Księstwie Warszawskim działali na zasadach wyznaczonych przez ustawę notarialną z 4 VIII 1808 r., bazującą na ustawie francuskiej z 16 III 1803 r. ${ }^{15}$ Byli to urzędnicy mianowani przez władzę zwierzchnia, ustanawiani dla przyjmowania aktów i umów posiadajacych cechy autentyczności takie same jak akty publiczne. Kontrolowali ich daty, przechowywali je oraz wydawali wyciagi. Dokumenty spisane przed notariuszem zyskiwały status prawomocnych wyroków, rękojmię notariusza oraz klauzulę egzekucyjną ${ }^{16}$.

Kontrakty kupna-sprzedaży nieruchomości, kontrolowane przez notariuszy, były także sprawdzane przez strony czynności prawnej, z reguły zainteresowane (przez sprzeczność swych interesów), aby wystawiane dokumenty odpowiadały rzeczywistości ${ }^{17}$.

${ }^{13}$ Położenia niektórych wsi nie udało się zlokalizować i w ich przypadku brak adnotacji o położeniu w powiecie, co było rzadkością.

14 J. Topolski, Uwagi o strukturze gospodarczo-społecznej Wielkopolski $w$ XVIII wieku, czyli dlaczego na jej terenie nie byto żydowskich karczmarzy, w: Żydzi w Wielkopolsce na przestrzeni dziejów, red. J. Topolski, K. Modelski, Poznań 1999, s. 74.

${ }_{15}$ H. Szymańska, J. Śmiałowski, Akta notarialne z terenu Królestwa Polskiego i ich wartość naukowa, „Archeion” 30, 1959, s. 46.

${ }_{16} \mathrm{~J}$. Kazimierski, Akta notarialne $i$ ich znaczenie dla badań historycznych XIX $w$., St. Źródł., t. 4, 1959, s. 110, 112.

17 J. Mazurkiewicz, dz. cyt., s. 122. 
Umowy kupna-sprzedaży nieruchomości zawierane w Księstwie Warszawskim nie musiały mieć formy aktu notarialnego, co więcej, wystarczała tylko forma ustna ${ }^{18}$. Kontrakty zawarte prywatnie z pominięciem urzędu notariusza nosiły często nazwę tzw. punktacji. Mogły być spisane tylko między stronami ${ }^{19}$ lub przed sołtysem ${ }^{20}$ czy magistratem miejskim ${ }^{21}$. O ich istnieniu dowiadujemy się niejednokrotnie tylko jeżeli zostały dołaczone do akt lub wspomniane w kontrakcie notarialnym. Pomimo wprowadzenia na mocy konstytucji z 22 VII 1807 r. całkiem nowego ustroju sądów, w pewnym zakresie cały czas działały dotychczasowe sądy wiejskie ${ }^{22}$, gdzie również dokonywano transakcji kupna-sprzedaży nieruchomości. Dla terenu Wielkopolski jedyna zachowana dokumentacją tego typu urzędu jest księga ławnicza wsi Kargowej (1617-1837). Z czterech ocalałych zapisek powstałych w okresie Księstwa Warszawskiego jedna dotyczy sprzedaży gospodarstwa chłopskiego $^{23}$. Biorac powyższe okoliczności pod uwagę, pełna rekonstrukcja rynku nieruchomości chłopskich na badanym terenie $\mathrm{w}$ przytoczonych cezurach czasowych jest niemożliwa, natomiast poniższa analiza może dać orientację w skali i charakterze zjawiska. Bez watpienia bowiem status prawny dokumentacji notarialnej stanowił zachętę, aby pomimo pewnych kosztów transakcje kupna-sprzedaży nieruchomości zawierać $\mathrm{w}$ formie urzędowej.

Stan stron stawających do kontraktów był identyfikowany na podstawie danych zamieszczanych w umowach, takich jak: miejsce zamieszkania, wykonywany zawód ${ }^{24}$ lub pełniona funkcja oraz tytulatura, która wciąż stosowały sądy i notariaty działające w Księstwie Warszawskim. Chłopów określano najczęściej słowami „pracowity” lub „uczciwy”"25,

18 W. Wójcikiewicz, dz. cyt., s. 46-47.

${ }^{19}$ W przywołanym przypadku spisaną prywatnie umowę dołączono do aktu notarialnego; Archiwum Państwowe w Poznaniu Oddział w Koninie (dalej: APP o/Konin), Akta notariusza Wilhelma Sztandke w Koninie (dalej: AnWSwK), sygn. 4, k. 445-446.

${ }^{20} \mathrm{~W}$ przywołanym kontrakcie chłop Walenty Wele oświadczył, że sprzedawany grunt nabył uprzednio przed urzędem sołeckim. O tego typu zdarzeniach możemy dowiadywać się przede wszystkim w sposób pośredni; APP o/Konin, Sąd Pokoju Powiatu Konińskiego (dalej: SPPK), Sprawy cywilne niesporne (dalej: Scn), sygn. 73, k. 72.

${ }^{21}$ APP o/Konin, AnWSwK, sygn. 3, k. 76-77.

${ }^{22}$ W. Sobociński, dz. cyt., s. 245.

${ }^{23}$ Księga tawnicza wsi Kargowej $w$ powiecie kościańskim 1617-1837, wyd. A. i A. Walawenderowie, Warszawa 1960 (Studia z Dziejów Gospodarstwa Wiejskiego, 3), z. 3, zapiska 332, s. 172.

${ }^{24}$ Chłopi określani byli m.in. jako okupnicy, czynszownicy czy gospodarze.

${ }_{25}$ Stownik języka polskiego, t. 4, red. A. Kryński, W. Niedźwiedzki, Warszawa 1952, s. 967; M. Kamler, Przemoc między szlachta $w$ Polsce w XVII w. - zjawisko masowe?, KH, t. 121, 2014, nr 3, s. 546. 
mieszczan - „sławetny”, „szlachetny”26, Żydów - „starozakonny”27, a szlachtę - „urodzony” lub „wielmożny”28. Stan części osób podpisujących umowy pozostał nierozpoznany.

Chłopi uczestniczyli w 96 (42\%) z 226 transakcji kupna-sprzedaży nieruchomości. Ich zestawienie podaje tabela 1 .

Tabela 1. Pochodzenie stanowe stron w kontraktach kupna-sprzedaży nieruchomości, w których co najmniej jedną stroną był chłop: Księstwo Warszawskie, powiat koniński, 1808-1815

\begin{tabular}{|l|l|c|c|}
\hline \multicolumn{2}{|c|}{ Pochodzenie stanowe strony } & \multirow{2}{|c|}{$\begin{array}{c}\text { Liczba } \\
\text { kontraktów }\end{array}$} & \% \\
\hline chłop & chłop & 36 & 37,5 \\
\hline szlachcic & chłop & 36 & 37,5 \\
\hline stan nierozpoznany & chłop & 17 & 18 \\
\hline chłop & szlachcic & 3 & 3 \\
\hline chłop & mieszczanin & 2 & 2 \\
\hline chłop & Żyd & 1 & 1 \\
\hline chłop & stan nierozpoznany & 1 & 1 \\
\hline Razem & & $\mathbf{9 6}$ & $\mathbf{1 0 0}$ \\
\hline
\end{tabular}

Źródło: APP o/Konin, AnWSwK, sygn. 3-10, 12-13; APP o/Konin, SPPK, Scn, sygn. 73-76.

Z powyższej tabeli wynika, że zdecydowaną większość umów (75\%) chłopi zawierali pomiędzy sobą lub kupując grunty od szlachty, co wskazuje na główne grupy społeczne, w obrębie których dokonywali oni obrotu nieruchomościami. Ponadto ludność chłopska w 93\% przypadków występowała jako strona kupująca (także od przedstawicieli swojego stanu). Włościanie chętniej nabywali niż pozbywali się gruntów (oprócz jednej wszystkie transakcje dotyczyły ziemi i budynków na wsiach). Zapewne widzieli więc zasadność tego typu inwestycji.

Zestawienie uczestników udokumentowanych 226 transakcji kupna-sprzedaży nieruchomości według przynależności stanowej podaje tabela $2^{29}$ :

${ }_{26}$ Stownik języka polskiego, t. 6, red. A. Kryński, W. Niedźwiedzki, Warszawa 1952, s. 207; W. Dworzaczek, Przenikanie szlachty do stanu mieszczańskiego $w$ Wielkopolsce $w$ XVI $i$ XVII w., PH, t. 47, 1956, nr 4, s. 657.

${ }^{27}$ Z. Filipiak, Projekt urzqdzenia ogólnego ludności żydowskiej w Księstwie Warszawskim z 1809 r., CPH, t. 68, 2016, nr 2, s. 148.

${ }_{28}$ Z. Gloger, Encyklopedia staropolska, t. 4, Warszawa 1972, s. 410-411.

${ }^{29}$ Zdarzało się, że w ramach jednego aktu sprzedawano działki kilku kupującym, stąd liczba uczestników transakcji była większa niż 452 . 
Tabela 2. Pochodzenie stanowe uczestników transakcji kupna-sprzedaży nieruchomości udokumentowanych przez notariat oraz sąd pokoju: Księstwo Warszawskie, powiat koniński, 1808-1815

\begin{tabular}{|l|c|c|}
\hline Pochodzenie stanowe strony & Liczba & \% \\
\hline chłopi & 162 & 33,5 \\
\hline mieszczanie & 161 & 33,5 \\
\hline szlachta & 89 & 18,5 \\
\hline Żydzi & 21 & 4,5 \\
\hline Stan nierozpoznany & 49 & 10 \\
\hline Razem & $\mathbf{4 8 2}$ & $\mathbf{1 0 0}$ \\
\hline
\end{tabular}

Źródło: APP o/Konin, AnWSwK, sygn. 3-10, 12-13; APP o/Konin, SPPK, Scn, sygn. 73-76.

Powyższa tabela pokazuje, że chłopi i mieszczanie stanowili w powiecie konińskim dwie grupy najczęściej zawierające kontrakty kupna-sprzedaży nieruchomości. Udział włościan można uznać za duży, choć oczywiście pozostający znacznie poniżej ogólnego udziału tego stanu w całości społeczności powiatu (ok. 80\%) ${ }^{30}$. Najprawdopodobniej głównym powodem takiej sytuacji były ograniczone możliwości finansowe części ludności chłopskiej. Dotyczyło to zwłaszcza bezrolnych ${ }^{31}$.

Z uwagi na brak podobnych studiów dotyczacych innych obszarów Księstwa dla znalezienia punktu odniesienia przeprowadzono badanie sondażowe akt notariusza Karola Paciorkowskiego w Błoniu (miasto powiatowe, departament warszawski), obejmujące 100 aktów notarialnych stanowiących całość dokumentacji wytworzonej przez tego urzędnika $\mathrm{w} 1810 \mathrm{r} .{ }^{32}$ Udało się wyszczególnić $\mathrm{w}$ nich 33 kontrakty kupna-sprzedaży nieruchomości. W 4 z nich brało udział 4 chłopów, stanowiąc 7,5\% ogółu uczestników tego rodzaju umów, a więc wyraźnie mniej niż w powiecie konińskim. Wydaje się, że na potrzeby sondażowe próba $\mathrm{z}$ jednego roku powinna być wystarczająca.

$\mathrm{Na}$ podstawie powyższego zestawienia można obserwować częstotliwość zawierania transakcji przez osoby z poszczególnych stanów.

\footnotetext{
${ }^{30}$ M. Kędelski, Ludność powiatu konińskiego na przełomie XVIII i XIX wieku, „Rocznik Koniński” 11, 1997, s. 35, 47.

${ }^{31}$ Ludność bezrolna stanowiła w 1810 r. ok. 52,2\% ogółu chłopów. Wśród rolnych w 1816 r. 55,6\% stanowili chłopi gospodarujący na podstawie lepszego prawa do ziemi (ok. 25\% ogółu). Wartości te dotyczą obszaru Wielkopolski, który w 1815 r. znalazł się pod panowaniem Prus. Dane dla wschodniej Wielkopolski powinny być zbliżone; S. Borowski, Kształtowanie się rolniczego rynku pracy..., s. 29.

32 Archiwum Państwowe w Warszawie Oddział w Grodzisku Mazowieckim, Kancelaria Paciorkowskiego Karola notariusza w Błoniu, sygn. 1, k. 240-658.
} 
W przypadku gdy za główne kryterium zostanie wzięta wartość gotówkowa podpisywanych umów przodować zaczną przedstawiciele szlachty.

Analizowane kontrakty kupna-sprzedaży gruntów chłopskich dotyczyły gospodarstw dysponujących tzw. lepszym prawem do ziemi, czyli własności użytkowej. Genezy tej formy użytkowania należy szukać w funkcjonujących już w średniowieczu tzw. prawach zakupnych. Najistotniejszym kryterium decydującym o tym, czy dane gospodarstwo funkcjonowało na lepszych prawach była zapisana w kontrakcie nieusuwalność z ziemi (liczona co najmniej w kilku dziesiątkach lat lub bez ograniczeń czasowych) ${ }^{33}$. Chłopi gospodarujacy na takich zasadach w niektórych okolicznościach również mogli być zmuszeni do sprzedaży swych gospodarstw lub wyznaczenia zdolnego następcy. Było to jednak możliwe w sytuacjach przewidzianych kontraktem lub okolicznościach skrajnych, takich jak: wyjątkowa niegospodarność lub popełnienie określonych przestępstw ${ }^{34}$. Oprócz nieusuwalności włościanie dysponujący lepszymi prawami cieszyli się również innymi przywilejami, do których należały: możliwość alienacji gospodarstw po uprzednim uiszczeniu na rzecz pana tzw. laudemium (czyli prowizji stanowiącej pewien procent - do 10\% - kwoty sprzedaży nieruchomości, należnej właścicielowi zwierzchniemu), sporządzanie darowizn, zamiana gospodarstw oraz dziedziczenie i przekazywanie zstępnym użytkowanych gruntów. Zazwyczaj potrzebna była na to zgoda dworu ${ }^{35}$. Nie wszystkie te możliwości musiały być uwzględnione w każdym kontrakcie. W źródłach pojawiały się różne terminy określające lepsze prawa do ziemi. Można wśród nich wymienić następujące: własność użytkowa (forma charakteryzująca się najszerszą gamą swobód), dzierżawa wieczysta, dzierżawa dziedziczna czy emfiteuza ${ }^{36}$. Różnice pomiędzy poszczególnymi formami lepszego prawa do ziemi były nieznaczne, przez co w praktyce administracyjnej, sądowej, a także w samych kontraktach mieszano niejednokrotnie wszystkie te terminy ${ }^{37}$. W czasach pruskich gospodarstwa chłopów dysponujących lepszymi prawami były wpisywane do

${ }^{33}$ S. Borowski, Ksztattowanie się rolniczego rynku pracy..., s. 48.

${ }_{34}$ Tenże, Rozwarstwienie wsi wielkopolskiej..., s. 47.

35 Tenże, Kształtowanie się rolniczego rynku pracy..., s. 48.

${ }^{36} \mathrm{O}$ różnych formach użytkowania gruntu przez chłopów w okresie przedrozbiorowym zob. J. Rutkowski, Poddaństwo wtościan $w$ XVIII wieku w Polsce i niektórych innych krajach Europy, w: tenże, Wieś europejska późnego feudalizmu (XVI-XVIII w.), Warszawa 1986, s. 132-135.

37 S. Borowski, Rozwarstwienie wsi wielkopolskiej..., s. 47; D. Wiśniewska-Jóźwiak, Dzierżawa wieczysta i emfiteuza w polskim prawie przedrozbiorowym, „Przegląd Nauk Historycznych" 13, 2014, nr 2, s. 133, 145. 
ksiag hipotecznych, co wyraźnie wzmacniało ich pozycję ${ }^{38}$. Włościanie korzystający z lepszych praw płacili panu gruntowemu przede wszystkim czynsz pieniężny oraz uiszczali daniny w naturze. Jeżeli odrabiali pańszczyznę, to tylko w minimalnym rocznym wymiarze ${ }^{39}$. Przebadane umowy spełniały te warunki. Przede wszystkim były zawierane wieczyście i mogły być przedmiotem oficjalnego obrotu.

Funkcjonuje opinia, że dla Rzeczypospolitej szlacheckiej terminu „własność podzielona” (z właścicielem zwierzchnim szlachcicem - dominium directum i właścicielem podległym chłopem - dominium utile) można używać w odniesieniu do gospodarstw chłopskich o lepszych prawach do ziemi dopiero od drugiej połowy XVIII w. Wiazało się to z wprowadzeniem pewnych uregulowań prawnych ${ }^{40}$ oraz z praktyką licznych oczynszowań dokonywanych głównie w dobrach magnackich i królewskich ${ }^{41}$. Konstruowanie umów dotyczących własności podzielonej zawieranych w Księstwie Warszawskim opierało się także na prawie pruskim ${ }^{42}$. Kształt kontraktów zależny był jednak w dużym stopniu od woli pana gruntowego ${ }^{43}$. Kodeks Napoleona odrzucał konstrukcję feudalnej własności podzielonej ${ }^{44}$. Tym samym zawieranie tego typu umów wbrew przepisom obowiązującego kodeksu cywilnego dowodzi równoczesnego funkcjonowania na obszarze Księstwa Warszawskiego różnych porządków prawnych.

Przebadane kontrakty układano według jednego schematu i zawierano zawsze w obecności dwóch lub czterech świadków, w zależności od tego, czy strony znane były notariuszowi osobiście ${ }^{45}$. Obowiązkowo umieszczano miejsce i datę sporządzenia aktu. Następnie wpisywano dane sprzedającego i kupującego oraz informacje na temat przedmiotu

38 T. Mencel, Zniesienie poddaństwa..., s. 29-30.

39 S. Borowski, Rozwarstwienie wsi wielkopolskiej..., s. 48-49.

40 Prawa kardynalne z 1768 r. pozwoliły nadawać wolnym ludziom bez względu na stan grunty prawem emfiteutycznym; Z. Radwański, J. Wassicki, Najważniejsze zmiany w polskim prawie cywilnym $w$ okresie oświecenia, CPH, t. 4, 1952, s. 70.

${ }^{41}$ Tamże, s. 71-73; zob. R. Orłowski, Oczynszowanie włościan w dobrach Andrzeja Zamoyskiego, „Annales Universitatis Mariae Curie-Skłodowska. Sectio H, Oeconomia" 1, 1967, s. 119-140.

${ }^{42}$ W. Wójcikiewicz, dz.cyt., s. 42 . O sytuacji prawnej tzw. właścicieli zob. Powszechne Prawo Kraiowe dla Państw Pruskich, cz. 2, t. 1, Poznań 1826, s. 364-372, tytuł 7, § 246-297; dziedzicznych czynszowników: tamże, cz. 1, t. 2, Poznań 1826, s. 405-423, tytuł 18, § 680-818; dziedzicznych dzierżawców: tamże, s. 539-545, tytuł 21, §187-226.

${ }^{43}$ H. Szymańska, dz. cyt., s. 66 (przyp. 36).

${ }^{44}$ W. Sobociński, dz. cyt., s. 219.

${ }_{45}$ T. Kubicki, Ustalanie tożsamości stron $w$ świetle obowiazujacych na ziemiach Królestwa Polskiego w XIX wieku przepisów notarialnych i hipotecznych a praktyka, „Studia z Dziejów Państwa i Prawa Polskiego” 15, 2012, s. 98-99. 
transakcji, zazwyczaj ze wskazaniem dokumentów potwierdzających fakt dysponowania daną własnościa, jak np. poprzednie kontrakty lub wpis do księgi hipotecznej. Sprzedający przekazując nieruchomość, deklarował, że „daje, daruje, przedaje i wiecznymi czasy odrezygnuje”"46. Był to stary nawykowy zwrot funkcjonujący przed wprowadzeniem Kodeksu Napoleona i ciagle stosowany w Księstwie Warszawskim ${ }^{47}$. Następnie podawano informację o cenie (wraz ze sposobem zapłaty) ${ }^{48}$ oraz ciężarach przypisanych do danej nieruchomości (publicznych, dominialnych, kościelnych). Choć według Kodeksu Napoleona sprzedaż była ważna bez tzw. tradycji (przeniesienie posiadania ${ }^{49}$ ), data dokonania tej czynności, niejednokrotnie $\mathrm{z}$ adnotacja o sankcji egzekucyjnej, zawsze pojawiała się w umowie. Zapewne także można to uznać za działanie nawykowe wynikające z przedrozbiorowych uwarunkowań prawnych. Często, choć nie zawsze, sprzedajacy zabezpieczał kupującego na całym swoim pozostałym majątku, potwierdzając tym samym, że sprzedana nieruchomość bezsprzecznie należała do niego - tzw. ewikcja ${ }^{50}$. Ponadto oświadczał swoją zgodę na wpis nowego właściciela do ksiag hipotecznych. Kontrakt kończyło złożenie podpisów przez strony, notariusza i świadków oraz wyliczenie kosztów aktu. Taksę notarialna regulował dekret Fryderyka Augusta z 14 III 1809 r. ${ }^{51}$ Notariusz koniński pobierał za przyjęcie aktu kwotę 8 zł. Przykładowo całość opłat wraz z wydanym wyciagiem wynosiła dla jednego kontraktu 18 zł i 10 gr $^{52}$.

Na 162 chłopskich kontrahentów własnoręczne podpisy złożyło 34 (ok. 21\%), pozostali podpisali się trzema krzyżykami. Zdolność wykonania własnoręcznego podpisu nie musiała być równoznaczna z umiejętnością czytania i pisania. Wydaje się, że 21-procentowy udział chłopów potrafiących się podpisać należy uznać za wysoki i najprawdopodobniej niereprezentatywny dla całości stanu chłopskiego zamieszkującego badany region. Przebadane przez autora dla potrzeb pracy magisterskiej akta sądu pokoju w Śremie (centralna Wielkopolska) z lat 1810-1812 wykazały piśmienność włościan na o wiele niższym poziomie $-12,1 \%{ }^{53}$.

${ }^{46}$ APP o/Konin, AnWSwK, sygn. 10, k. 50.

47 J. Mazurkiewicz, dz. cyt., s. 117.

${ }^{48}$ Przy sprzedaży gruntu przez szlachcica chłopu opłata nazywana była jako wkupne - grundgeld.

49 W. Sobociński, dz. cyt., s. 230.

50 Z. Gloger, Encyklopedia staropolska, t. 2, Warszawa 1972, s. 138.

${ }^{51}$ Dziennik Praw Księstwa Warszawskiego, t. 1, s. 213-217.

${ }^{52}$ APP o/Konin, AnWSwK, sygn. 9, k. 454.

${ }^{53}$ T. Opaliński, Stan chtopski w Księstwie Warszawskim w świetle akt sadowych, Warszawa 2018, mps pracy magisterskiej, Archiwum Prac Dyplomowych Uniwersytetu Kardynała Stefana Wyszyńskiego, s. 101. 
Trzeba także nadmienić, że w badanej grupie znaczny, jeżeli nie przeważajacy udział mieli chłopi niemieckojęzyczni, którzy najprawdopodobniej częściej posługiwali się pismem niż włościanie polskojęzyczni. Powyższy fakt dodatkowo osłabia reprezentatywność analizowanej grupy pod względem piśmienności.

Przedstawiciele szlachty jako sprzedający zawarli z chłopami 36 kontraktów kupna-sprzedaży gruntów, przy czym kupujący stanowili tu grupę 62 osób. W ramach jednego dokumentu sprzedawano niejednokrotnie kilka działek różnym nabywcom.

W przypadku 34 umów (60 kupujacych) można mówić o sprzedaży własności podległej przez właściciela zwierzchniego. Analiza tych przypadków pomoże naświetlić warunki, jakie szlachta narzucała w takich sytuacjach chłopom.

Przedmiot sprzedaży stanowiły grunty, zapewne w większości bez budynków i zasiewów. Wynika to z informacji, że dziedzic sprzedawane ziemie przeznaczył świeżo pod zasiedlenie (nowe działki wyznaczał mierniczy, tzw. konduktor) lub z tego, że określał warunki, na jakich nabywajacy będą mogli uzyskać od dworu drewno na budowę domów i budynków gospodarczych ${ }^{54}$. Inna sytuacja miała miejsce w przypadku sprzedaży czterem nowym osadnikom znacznej części wsi Drążno (10 hub - ok. 179 ha $^{55}$ ), przed którą dziedzic najprawdopodobniej wyrugował dotychczas mieszkających i gospodarujących tam włościan, a ich zabudowania włączył do przedmiotu umowy ${ }^{56}$. To jedyny kontrakt przynoszacy informacje o odbywających się w badanym regionie rugach ${ }^{57}$.

Kontrakty zawierano bez jakichkolwiek ograniczeń czasowych. W umowach padało określenie: „na wieczne czasy”.

Rozpiętość sprzedawanych powierzchni zamykała się w szerokim przedziale i wynosiła od 2,33 mórg chełmińskich (ok. 1,4 ha) do

${ }^{54}$ APP o/Konin, AnWSwK, sygn. 6, k. 160.

${ }_{55}$ Miarami powierzchni na początku XIX w. w Wielkopolsce była licząca $5985 \mathrm{~m}^{2}$ morga chełmińska (najczęściej stosowana) oraz mniejsza od niej morga magdeburska, mająca w przeliczeniu na jednostki metryczne $2553 \mathrm{~m}^{2}$. Wyższą jednostkę stanowiła huba - odpowiednik włóki, licząca 30 mórg (chełmińskich lub magdeburskich); I. Ihnatowicz, A. Biernat, Vademecum do badań nad historia XIX i XX wieku, Warszawa 2003, s. $44,46$.

${ }^{56}$ APP o/Konin, SPPK, Scn, sygn. 74, k. 339-341.

57 Stanisław Borowski szacował liczbę chłopów wielkopolskich, którzy utracili swe gospodarstwa w okresie Księstwa Warszawskiego, na ok. 4,7\% ich populacji, do liczby tej wliczając też tych opuszczających swe osady dobrowolnie i przenoszących się w inne rejony kraju czy też do miast, co ułatwiało im zniesienie poddaństwa. Wydaje się więc, że zjawisko rugów krótko po 1807 r. nie przybrało jeszcze szerszych rozmiarów; tenże, Kształtowanie się rolniczego rynku pracy..., s. 43-44, także przyp. 75. 
wspomnianych już 10 hub chełmińskich (ok. 179 ha) sprzedanych czterem osadnikom (podziału pomiędzy każdego z nich nie znamy).

Najczesściej przedmiotem obrotu były grunty o wielkości 15 mórg chełmińskich (półhubowe, ok. 8,9 ha), w następnej zaś kolejności mierzące 7,5 mórg chełmińskich (ćwierćhubowe, ok. 4,5 ha) oraz 10 mórg chełmińskich (ok. 5,9 ha).

Analizowane kontrakty zawsze zawierały szczegółowy wykaz obowiązkowych powinności. Najważniejszą z nich był czynsz pieniężny. Wyznaczano go w wymiarze rocznym od 1 morgi (2,5-6 zł od morgi chełmińskiej, 3zł od morgi magdeburskiej) lub 1 huby (78-100 zł od huby chełmińskiej), a następnie naliczano proporcjonalnie do sprzedanego obszaru. W przypadku działek o powierzchni 15 mórg chełmińskich, będacych najczęściej przedmiotem obrotu, czynsz roczny wynosił od 60 do 90 zł. Wysokość tej opłaty zależała zapewne od jakości ziemi, na co wpływ mogło też mieć jej położenie (sporo sprzedanych działek przylegało do brzegów Warty, ich fragmenty były prawdopodobnie okresowo zalewane). Ponadto niższy czynsz (w przeliczeniu na 1 morgę) płacili właściciele większych, około jednohubowych gruntów ${ }^{58}$.

Daniny w naturze pojawiały się rzadziej (17 przypadków) i wynosiły od 1 huby chełmińskiej: 2 gęsi, 2 kapłony, 4 wiertele ${ }^{59}$ owsa oraz kopę jaj z możliwością zamiany na 2 złote $^{60}$. Młynarze obowiązani byli mleć wyznaczone ilości zboża.

W części przypadków (16) do umowy wpisano posługę transportowa ${ }^{61}$.

Odrabianie pańszczyzny (zaciąu) przewidywało około $2 / 3$ kontraktów (43). Zawsze wyznaczano ją w wymiarze rocznym. W przypadku najczęściej sprzedawanych działek o powierzchni 15 oraz 7,5 mórg chełmińskich wynosiła ona odpowiednio 12 i 6 dni ręcznych ${ }^{62}$. W 8 umowach

${ }^{58}$ Czynsz z takich gospodarstw nie przekraczał 100 zł od 1 huby chełmińskiej.

59 Wiertel (ok. 60,3 l) stanowił połowę korca miary skarbowej warszawskiej; B. Wietrzychowski, O finansach komunalnych miasta Poznania roku 1780 i wspótczesnych (studium porównawcze), „Kronika Miasta Poznania” 15, 1937, nr 3, s. 273-274; B. Więcławski, Zarys problematyki miar powierzchni gruntów oraz produkcji zbożowej we wsiach miasta Poznania w XVIII wieku, „Studia i Materiały do Dziejów Wielkopolski i Pomorza” 15, 1983, nr 1, s. 55; I. Ihnatowicz, A. Biernat, dz. cyt., s. 48.

${ }^{60}$ APP o/Konin, SPPK, Scn, sygn. 74, k. 344.

${ }^{61}$ Dla przykładu chłopi z Olędrów Tury mieli dostarczyć raz w roku do Poznania 1 furę zboża dworskiego (nie więcej niż 10 wierteli); APP o/Konin, AnWSwK, sygn. 7, k. 63-64. Inne posługi transportowe miały podobny wymiar.

${ }^{62} \mathrm{APP}$ o/Konin, AnWSwK, sygn. 4, k. 442; tamże, sygn. 6, k. 351. W Wielkopolsce na określenie pańszczyzny niewykonywanej zaprzęgiem funkcjonował termin „pańszczyzna ręczna”, dla innych terenów można spotkać się z określeniem „pańszczyzna piesza"; S. Borowski, Kształtowanie się rolniczego rynku pracy..., s. 67. 
określono jej wymiar od 1 huby chełmińskiej na 5 dni bydłem i 5 dni ręcznych. Przelicznik dni ręcznych do sprzężajnych dla terenu Wielkopolski wynosił $2: 1^{63}$. Kontrakt zawarty przez hrabiego Władysława Gurowskiego z 8 chłopami z Olędrów Tury przewidywał odrobienie z 1 huby chełmińskiej 8 dni ręcznych oraz zaoranie 2 mórg chełmińskich ${ }^{64}$. Więcej przypadków pańszczyzny wymiarowej nie udało się stwierdzić. Z części umów wynika, że pańszczyzna miała być wykonywana od wschodu do zachodu słońca ze zwyczajową 1 godziną odpoczynku w południe $^{65}$. Szlachta pozostawiała sobie wolność wyboru terminu odrobienia tej powinności. Kilka kontraktów zawierało wyraźne zastrzeżenie, aby pańszczyzna odpracowana została „bez sprzeczki”, co wskazuje na występujace $\mathrm{w}$ tym zakresie konflikty ${ }^{66}$. W jednym kontrakcie, aczkolwiek zawartym z osobą o nieokreślonej przynależności stanowej, dwór zdefiniował przelicznik dni pańszczyźnianych do gotówki na 4 zł za 1 dzień sprzężajny i 2 zł za 1 dzień ręczny ${ }^{67}$. Najprawdopodobniej więc w pewnych okolicznościach mogło dochodzić do okupu pańszczyzny.

Niekiedy dwór udzielał wolnizny od opłat czynszu (zazwyczaj 3 lata) i odrobienia robocizn $(1 \mathrm{rok})^{68}$.

Dominia zawsze rezerwowały dla siebie trzy podstawowe monopole: propinacji, mlewa i polowania oraz często wyłączność rybołówstwa na wodach wchodzących w skład sprzedanych gruntów. Wśród pozostałych warunków wyszczególnionych w umowach należy wymienić możliwość składowania przez dwór drewna w bliskości rzeki Warty, za co chłopi uzyskiwali ulgę w czynszu oraz rezerwację własności rosnących na działkach dębów lub innych drzew (np. w okresie 3 lat od momentu sprzedaży).

Do wyjątkowo występujących powinności trzeba zaliczyć obowiązek uczestnictwa w polowaniach na wilki, zapisany we wspomnianym już kontrakcie hrabiego Gurowskiego z ośmioma olędrami.

${ }^{63}$ S. Borowski, Ksztattowanie się rolniczego rynku pracy..., s. 68-69.

${ }^{64}$ APP o/Konin, AnWSwK, sygn. 7, k. 62-63.

${ }_{65}$ APP o/Konin, AnWSwK, sygn. 6, k. 178.

${ }_{66}$ APP o/Konin, AnWSwK, sygn. 4, k. 446.

${ }^{67}$ APP o/Konin, AnWSwK, sygn. 8, k. 182-183. Przy takim przeliczniku gospodarstwo kmiece w dobrach Konarzewo pod Poznaniem obciazżone rocznie 624 dniami pańszczyzny ręcznej musiałoby $\mathrm{w}$ zamian oddać dla dworu niebagatelna kwotę 1248 zł. W porównaniu główne obciążenie 1-hubowego gospodarstwa okupnego (100 zł czynszu rocznie, 5 dni pańszczyzny sprzężajnej i 5 dni ręcznej) wydaje się niewielkie. Oczywiście do rachunku tego należy podchodzić bardzo ostrożnie z racji tego, że dwór w ustalonym przez siebie przeliczniku zastosował wyśrubowana, najpewniej znacznie zawyżoną wartość dniówki pańszczyźnianej; S. Borowski, Kształtowanie się rolniczego rynku pracy..., s. 77.

68 APP o/Konin, AnWSwK, sygn. 6, k. 359-360. 
Kupujący mieli obowiązek ponosić wszelkie ciężary publiczne i kościelne, niewymieniane jednak w szczegółach. Nie mogli też żądać od dworu ulg w opłatach dominialnych na te cele, co zapewne było częstą praktyka ${ }^{69}$.

Z pastwisk i lasów dworskich nabywający grunty korzystali po spełnieniu odpowiednich warunków. Dominia żądały za to np. opłaty od sztuki pasionego bydła $(15 \mathrm{gr})^{70}$ lub umożliwiały zbiór drewna opałowego raz w tygodniu bez użycia siekiery ${ }^{71}$. Widać tu odejście od zwyczajowych darmowych służebności pastwiskowych oraz leśnych, przysługujących chłopom.

We wszystkich analizowanych kontraktach po spełnieniu odpowiednich warunków nabywający zyskiwali możliwość pełnego dysponowania zakupioną ziemia. Dwór udzielał pozwolenia „używania gruntu nabytego jako swoją własność, sprzedania, odstapienia, darowania i co chce robienia" 72 lub „przedający pozwala kupującemu grunt swój przedać, zamienić, darować, i ku najlepszemu użytkowi obrócić”73. Z powyższego zapisu można wnioskować, że kupujący mieli swobodę kształtowania gospodarki rolnej na swoich gruntach, czyli sami decydowali o sposobie wykorzystania ziemi ${ }^{74}$. W analizowanych kontraktach brak też klauzul zabraniających podziału ziemi oraz zbywania części gospodarstw.

Dysponowanie zakupionym obszarem mogło odbywać się za wiedzą i zgodą dworu (41), tzw. konsensem ${ }^{75}$. Z zapisów kontraktów może wynikać, że w części przypadków dokument ten potrzebny był tylko do sprzedaży (18), nieco częściej zaś wymagano go także do innych czynności, takich jak: darowizna, zamiana czy zastaw (43). Dwór ośmiokrotnie rezerwował dla siebie w takich sytuacjach prawo pierwokupu ${ }^{76}$. W części kontraktów (10) brak jakichkolwiek zapisów o konsensie lub pierwokupie. Trudno jednoznacznie stwierdzić, co taka sytuacja mogła oznaczać.

Tylko raz dwór zrezygnował w zapisach kontraktu z pobierania laudemium w przypadku zbycia gospodarstwa przez właściciela podległego. Wynosiło ono zazwyczaj 10\% (dziesiąty grosz) od kwoty sprzedaży. Opłaty 5\% i 3\% występowały zdecydowanie rzadziej (3 razy). W analizowanych umowach laudemium należne było w przypadku sprzedaży,

\footnotetext{
69 APP o/Konin, AnWSwK, sygn. 4, k. 442.

${ }^{70}$ APP o/Konin, AnWSwK, sygn. 6, k. 170.

1 APP o/Konin, AnWSwK, sygn. 7, k. 65.

2 APP o/Konin, AnWSwK, sygn. 4, k. 441.

APP o/Konin, AnWSwK, sygn. 6, k. 354-355.

${ }^{74}$ Niektóre kontrakty uzależniały ilość trzymanego bydła od powierzchni gruntu.

${ }^{75}$ APP o/Konin, AnWSwK, sygn. 6, k. 377.

${ }^{76}$ APP o/Konin, AnWSwK, sygn. 7, k. 64.
} 
a także zamiany (14 przypadków) gruntów. W umowie z ośmioma chłopami z Olędrów Tury dziedzic wyraźnie zaznaczył, że nie będzie pobierał tej opłaty w sytuacji przepisania gospodarstwa dzieciom, sukcesorom lub prawnie ich zastępujacym ${ }^{77}$, co wskazuje, że takie praktyki mogły mieć miejsce w innych przypadkach. Sankcją za zaniżanie sumy sprzedaży była najczęściej kara pieniężna lub unieważnienie samej transakcji $^{78}$. Niewątpliwie więc zatajanie faktycznych kwot transakcji niekiedy występowało.

W kilku przypadkach do umów zostały dołączone oryginały konsensów i poświadczeń opłaty laudemium ${ }^{79}$. Były to krótkie, kilkuzdaniowe dokumenty.

Najpoważniejsze sankcje, czyli utrata własności, groziły chłopu w przypadku zalegania z 2-3-letnim czynszem (wpisane do 21 umów) ${ }^{80}$ oraz właśnie za zaniżanie kwoty sprzedaży $(5)^{81}$. Praktyczny wymiar egzekwowania takich kar pokazuje przypadek umowy hrabiego Ignacego Trzcińskiego z grupa 12 kolonistów (wieś Oleśnica), z których część nie płaciła czynszu co najmniej od 2 lat $^{82}$. Zostali oni przeniesieni na gospodarstwa mniejsze we wsi Święci, w ten sposób spłacając dług.

Kontrakty określane były jako „prawo emfiteutyczne” (najczęściej) ${ }^{83}$, „prawo emfiteutyczne dziedziczne” ${ }^{44}$, „prawo wieczno-dzierżawne czyli emfiteutyczne”85, a także „prawo emfiteutyczne własności”"86. Na przełomie XVIII i XIX w. terminu „emfiteuza” używano na ziemiach polskich najczęściej w odniesieniu do prawa długoterminowego użytkowania gruntu (do 50 lat) z czynszem ustalonym na stałej wysokości, niezależnym od wysokości plonów $\mathrm{w}$ danym roku, oraz $\mathrm{z}$ obowiazkiem prowadzenia działań podnoszących jakość gruntu, np. melioracji ${ }^{87}$. Z przeanalizowanych dokumentów wynika, że przynajmniej w rejonie wschodniej Wielkopolski używano tego pojęcia na określenie kontraktów dotyczących sprzedaży gruntowej własności użytkowej, zawieranych bez ograniczeń czasowych, z możliwością pełnego dysponowania nieruchomością oraz bez większych ograniczeń w użytkowaniu ziemi. Tylko z takimi

\footnotetext{
77 APP o/Konin, AnWSwK, sygn. 7, k. 64.

78 APP o/Konin, AnWSwK, sygn. 6, k. 163.

79 APP o/Konin, AnWSwK, sygn. 4, k. 143; tamże, sygn. 10, k. 248.

${ }^{80}$ APP o/Konin, AnWSwK, sygn. 4, k. 488, 494-495.

${ }^{81}$ APP o/Konin, SPPK, Scn, sygn. 74, k. 346.

${ }^{82}$ APP o/Konin, AnWSwK, sygn. 12, k. 160-178.

${ }^{83}$ APP o/Konin, AnWSwK, sygn. 4, k. 458.

84 Tamże, k. 512.

${ }^{85}$ APP o/Konin, AnWSwK, sygn. 7, k. 60.

${ }^{86} \mathrm{APP}$ o/Konin, AnWSwK, sygn. 6, k. 159-160.

87 D. Wiśniewska-Jóźwiak, dz. cyt., s. 136-137.
} 
przypadkami mamy tu do czynienia. Pokazuje to płynność i wieloznaczność terminów opisujących prawa gruntowe w okresie przeduwłaszczeniowym. Sami nabywcy najczęściej określani byli jako „właściciele”88, ale można też spotkać takie sformułowania jak „posiadacz czyli właściciel” ${ }^{89}$ czy „posiedziciel” ${ }^{90}$, co także wskazuje na nieostre rozumienie istotnych pojęć funkcjonujących w ówczesnej dokumentacji urzędowej.

Powstaje pytanie, kim byli nabywający grunty chłopi. Analizowane przekazy nie dostarczają w tym względzie zbyt wielu informacji, można jednak postawić pewne hipotezy. Niektórzy z nich zapewne powiększali już użytkowane gospodarstwa ${ }^{91}$. Być może wywodzili się z rodzin dysponujacych zasobami gotówki i odchodzili „na swoje”. Nie można też wykluczyć lepiej sytuowanych kmieci, chcących wejść do grupy czynszowników. Niemal wszyscy uczestniczący w umowach włościanie wskazali miejsce swego zamieszkania w powiecie konińskim (nieliczni $\mathrm{w}$ powiatach sasiednich). Brak natomiast informacji o nowych kolonistach, przybywajacych spoza granic Księstwa.

Niewątpliwie duża część chłopów kupujących oraz sprzedających grunty $\mathrm{w}$ powiecie konińskim posługiwała się językiem niemieckim i nie znała polskiego, co wskazuje na aktywność inwestycyjna niemieckojęzycznych przedstawicieli tego stanu. W 32 umowach pojawiła się informacja, że treść kontraktu została przetłumaczona przez notariusza właśnie na niemiecki, a zapewne w części pomimo faktu tłumaczenia dokumentów taki zapis został pominięty. Określenie na podstawie imion i nazwisk, jak duża była to grupa będzie trudne m.in. dlatego, że pewien odsetek ludności Wielkopolski nosił nazwiska niemieckie sięgające swymi korzeniami kolonizacji średniowiecznej oraz dlatego też, że część olędrów, zwłaszcza katolików, w okresie przedrozbiorowym przeszła proces polonizacji i od dawna posługiwała się językiem polskim, mimo niemieckobrzmiących nazwisk ${ }^{92}$.

$\mathrm{Z}$ analizowanego materiału wynika, że ze strony szlachty osobą najaktywniej prowadząca akcję osadniczą był ,jaśnie wielmożny” Adam Bielski, poseł powiatu konińskiego na sejm Księstwa Warszawskiego. Sprzedawał on grunty głównie we wsiach Drążno, Piersk, Roztoka. Zawarł 26 kontraktów z 34 chłopami, w większości tworząc nowe gospodarstwa. Nie należy tego traktować jako formy parcelacji majątku. Sprzedający

\footnotetext{
${ }^{88}$ APP o/Konin, AnWSwK, sygn. 6, k. 216.

${ }^{89}$ APP o/Konin, AnWSwK, sygn. 9, k. 377.

${ }_{90}$ APP o/Konin, AnWSwK, sygn. 4, k. 442.

${ }^{91}$ Występują osoby o tych samych danych, kupujące kilka działek w różnym czasie.

92 W. Rusiński, Osady tzw. „Olędrów” w dawnym woj. poznańskim, Kraków 1947, s. $33-34$.
} 
pozostawał właścicielem zwierzchnim gruntu ze wszystkimi przysługujacymi mu w takiej sytuacji prawami.

Proces powstawania kolejnych osad odbywał się również przy udziale pośredników. Przykładem może być seria kontraktów zawartych przez nierozpoznanego stanowo Karola Borowskiego z grupa 16 chłopów i 2 mieszczan $^{93}$. Wszystkie dotyczyły sprzedaży działek o powierzchni $1 / 2$ huby chełmińskiej. Wykonał on tym samym warunki umowy zawartej z „jaśnie wielmożną” Konstancją Mielżyńska, mówiące o osadzeniu 18 gospodarzy. W jego władaniu pozostała najprawdopodobniej 1 huba chełmińska gruntu. Niestety wszystkie szczegóły (powinności, konsens itd.) znajdowały się w umowie bazowej, niedołączonej do aktów. Odsyłały do niej tylko poszczególne umowy.

Warto poruszyć też kwestię sprzedaży ziemi przez właścicieli zwierzchnich (szlachtę) właścicielom podległym, również wywodzącym się ze stanu szlacheckiego. Temat ten, przynajmniej dla okresu Księstwa Warszawskiego, nie został dotąd szerzej opracowany. Można przywołać sześć takich przypadków. Kształt kontraktu był identyczny jak w sytuacjach, gdy działki nabywali chłopi. Umowy zawierały zapisy o konsensie, laudemium i obowiązku wywiązywania się z powinności, w tym odrabianiu pańszczyzny. Dla przykładu umowa zawarta pomiędzy wspomnianym już posłem Bielskim a komisarzem ekonomicznym jednego z jego folwarków, „urodzonym” Janem Terpołowskim, dotycząca 1/2 huby chełmińskiej, zawierała obowiązek odpracowania 12 dni ręcznych w roku ${ }^{94}$. Sprzedajacy zobowiązał jednak komisarza, aby osadził u siebie jedna rodzinę, która rzeczony zaciąg odrabiałaby za niego. Takiego zalecenia nie zawierał natomiast inny kontrakt, podpisany przez Bielskiego z leśniczym swych dóbr (także najprawdopodobniej szlachcicem), zobowiązujący go również do odrabiania kilkunastu dni pańszczyzny rocznie ${ }^{95}$.

Wydaje się więc, że przynależność stanowa nie odgrywała w badanym okresie większej roli jeżeli chodzi o warunki stawiane przy sprzedaży gruntów właścicielowi podległemu.

Kształt kontraktów wykazywał duże podobieństwo do umów zawieranych przez szlachtę $\mathrm{z}$ chłopami w XVIII w. na terenie Wielkopolski, w których również umieszczano punkty dotyczące powinności, służebności czy konsensu ${ }^{96}$. W analizowanych dokumentach zawierano nie-

${ }_{93}$ APP o/Konin, AnWSwK, sygn. 4, k. 150-214.

94 Tamże, k. 496-502.

95 Tamże, k. 539-545. Z kontraktem zachowała się mapa gruntów.

${ }_{96}$ Za porównanie moga posłużyć kontrakty zawarte z chłopami przez Teofilę Działyńską w dobrach kórnickich, podpisywane w latach czterdziestych XVIII w. i późniejszych; Biblioteka Kórnicka, Rękopisy, sygn. BK 02702, k. 23-26, 32; BK 02705, 
kiedy zwroty obrazujące patrymonialny stosunek szlachty do kupujacych, wyrażajacy się np. w wymaganiu od nich wiernego przywiazania i posłuszeństwa, co podkreślało miejsce w hierarchii społecznej ${ }^{97}$. W użyciu były też takie określenia jak nadanie przywileju lub wprost nazwanie sprzedajacego prawodawca ${ }^{98}$. Nawiazywało to do przedrozbiorowych, prawodawczych (zwłaszcza w odniesieniu do terenu własnych dóbr) uprawnień szlachty.

Przebadane umowy, podpisywane w czasach Księstwa Warszawskiego, cechowały jednak istotne różnice w porównaniu do tych zawieranych jeszcze w Rzeczypospolitej szlacheckiej. Po pierwsze dokonywano ich przed urzędnikiem państwowym, co nadawało im wspomniane już cechy dokumentu publicznego. W relacjach: prywatny pan gruntowy chłop pojawiał się więc trzeci czynnik - państwo, mogące spełniać rolę arbitra. Ponadto w przeciwieństwie do kontraktów przedrozbiorowych brak w nich paragrafów udzielających uprawnień jurysdykcyjnych sołtysom i przysiężnym oraz punktów mówiących o zakresie władzy sądowniczej dworu. Wynikało to z przepisów konstytucji powołujacej ogólnopaństwowy system sądów dla wszystkich obywateli bez różnicy stanu.

Powstaje pytanie, na ile trwałe były postanowienia zawarte w umowach, zwłaszcza te dotyczące zakresu różnych powinności. Z lat funkcjonowania Prus Południowych zachowały się dane o częstych procesach wytaczanych przez chłopów (głównie olędrów) dziedzicom podnoszącym czynsz czy pańszczyznę wbrew zapisom przywilejów ${ }^{99}$. Również w analizowanych aktach notarialnych znajduje się ugoda zawarta pomiędzy „wielmożnym” Janem Gałczyńskim a ośmioma chłopami z Olędrów Gadowskich, kończąca kilkuletni spór pomiędzy stronami, dotyczący właśnie wymiaru świadczeń. W tym przypadku pierwszy kontrakt podpisany został w $1786 \mathrm{r}$., a więc jeszcze $\mathrm{w}$ przedrozbiorowej rzeczywistości prawnej ${ }^{100}$.

Można przypuszczać, że zawarcie umowy przed notariuszem, co rodziło wspomniane już skutki prawne, oraz wpisanie go do ksiag hipotecznych (informacje takie zawierały wszystkie umowy), gdzie odnotowywane były przypisane do gruntu powinności ${ }^{101}$, poprawiło sytuację chłopa w ewentualnych sporach sądowych z dziedzicem. Rozstrzyganiem takich

k. 2-4; BK 02709, k. 205. Zob. także przywilej dla Olędrów Gadowskich z 1786 r.; APP o/Konin, AnWSwK, sygn. 5, k. 216-229.

97 APP o/Konin, AnWSwK, sygn. 4, k. 481.

98 APP o/Konin, AnWSwK, sygn. 7, k. 58.

${ }^{99}$ D. Łukasiewicz, Uwagi o położeniu chłopów pod zaborem pruskim (Prusy Południowe i Zachodnie) w końcu XVIII i na poczqtku XIX w., PH, t. 103, 2012, nr 2, s. 322.

100 APP o/Konin, AnWSwK, sygn. 5, k. 207-232.

101 T. Mencel, Chtopi w wyborach..., s. 111. 
konfliktów miał się zajmować sąd państwowy. Powraca więc tu kwestia państwa jako arbitra wchodzącego aktywnie pomiędzy dwie strony umowy: szlachcica i chłopa, czego brakowało w okresie przedrozbiorowym.

Przebadane przez autora dla potrzeb pracy magisterskiej akta sądu pokoju w Śremie z lat 1810-1812 nie wykazały żadnych spraw spornych wytaczanych szlachcie przez chłopów, a dotyczących wspomnianych problemów ${ }^{102}$. Odnotowano natomiast cały szereg procesów prowadzonych pomiędzy tymi stanami odnośnie do innych konfliktów. Niewykluczone więc, że na obszarze Wielkopolski, w nowej pod wieloma względami rzeczywistości prawnej Księstwa, zapisy kontraktów o gruntową własność podzieloną były w większości przestrzegane ${ }^{103}$.

Analiza umów, w których to chłopi występowali jako sprzedający lub kupowali grunty od innych właścicieli podległych (3 przypadki), pomoże określić, na ile warunki zawarte w kontraktach (zwłaszcza konsens) ograniczały swobodę obrotu.

Kontraktów takich udało się wyszczególnić 44. Kupujacymi byli w większości inni chłopi, czyli osoby również trudniące się rolnictwem, a także trzech przedstawicieli szlachty (m.in. ekonom i pisarz prowentowy) oraz dwóch mieszczan.

W tych przypadkach przedmiotem sprzedaży były całe gospodarstwa z budynkami oraz zazwyczaj zasiewami. Niekiedy te ostatnie w pewnym zakresie (w postaci zbiorów) rezerwował dla siebie dotychczasowy użytkownik. Trzykrotnie przedmiotem sprzedaży były młyny (wodne i wietrzne) wraz z przyległymi do nich gruntami.

Wielkość sprzedawanych gospodarstw wahała się w przedziale od 7 mórg magdeburskich (ok. 1,8 ha) do 1 huby chełmińskiej (ok. 17,9 ha). Najczęściej sprzedawane powierzchnie wynosiły: 15 mórg chełmińskich (ok. 8,9 ha) - 11 umów oraz 1 hubę chełmińska - 7 przypadków.

Kontrakty te były w swej treści krótsze niż umowy nabycia gruntu od właściciela zwierzchniego. Nie opisywano w nich drobiazgowo powinności, wspominając jedynie, że obowiązek ich odrobienia spoczywa na kupujacym. Po szczegóły odsyłano niejednokrotnie do poprzednich przywilejów zawartych z właścicielem zwierzchnim.

Przy sprzedaży gruntu najistotniejszym ograniczeniem była konieczność uzyskania zgody (konsensu) dworu na taką czynność. W sytuacji omawianych tu 44 kontraktów kupna-sprzedaży gospodarstw chłopskich dokument ten wymagany był dla $30 \mathrm{z}$ nich.

102 T. Opaliński, dz. cyt.

${ }^{103}$ Dalsze badania w tym zakresie moga być prowadzone w zespole Trybunał Cywilny Kaliski przechowywanym w AGAD w Warszawie. 
Najczęściej konsens w formie pisemnej przedkładano do umowy ${ }^{104}$. Niekiedy zgody udzielał sam dziedzic, obecny w kancelarii. Brak też wzmianek o trudnościach czynionych w tym względzie chłopom. Kilkukrotnie (9 razy) dokument ten nie został dostarczony w dniu podpisania aktu notarialnego. W zamian pojawiały się deklaracje o dopełnieniu tej czynności w najbliższym czasie. Chłopi zazwyczaj nie podawali przyczyn takiego zaniechania lub tłumaczyli się trudnościami w dotarciu do dziedzica albo, jak w przypadku „uczciwego” Stanisława Sobczaka, zapewniali, że zgody dworu, a także poświadczenia opłaconego laudemium po prostu zapomnieli zabrać z domu ${ }^{105}$.

We wszystkich powyższych dziewięciu przypadkach zawarto kontrakty kupna-sprzedaży gospodarstw. Tym samym brak przedłożenia do aktu notarialnego aktualnego konsensu dworu nie stanowił żadnej przeszkody w jego podpisaniu. Działo się tak pomimo wyraźnych rozporządzeń rządowych, aby notariusze przyjmowali umowy dopiero po okazaniu wymaganych dokumentów ${ }^{106}$. Praktyka pokazuje więc, że zgoda dworu na sprzedaż gruntów, zwłaszcza w przypadku gdy nabywał go inny rolnik, nie była trudna do uzyskania, a niejednokrotnie strony oraz notariusz traktowali ją jako czystą formalność.

Podobnie rzecz się miała $\mathrm{w}$ sytuacjach niedostarczenia $\mathrm{w}$ dniu podpisania aktu poświadczenia opłaconego laudemium (9 przypadków).

$\mathrm{Z}$ zapisów części kontraktów z właścicielem zwierzchnim wynikało, że dwory wymagały konsensu także przy przekazywaniu gospodarstw następcom. Analiza trzynastu tego typu umów wykazała, że konsens został przedłożony dwa razy ${ }^{107}$. W pozostałych przypadkach brak w ogóle zapisów dotyczących zgody dominium na taką czynność, co może świadczyć zarówno o braku podobnych wymogów, jak i mniej aktywnej ingerencji dworów w procesy dziedziczenia majątku przez chłopów. Trzeba też wziać bod uwagę uchybienie samego notariusza. O tej ostatniej kwestii będzie jeszcze szerzej mowa.

Prawdopodobnie dwory nie utrudniały włościanom obrotu całymi gospodarstwami m.in. dlatego, że stanowiło to dla nich dodatkowe źródło gotówki w postaci wysokiego, najczęściej 10-procentowego laudemium. Niewykluczone natomiast, że dominia regulowały kwestie

104 APP o/Konin, AnWSwK, sygn. 10, k. 31.

105 APP o/Konin, AnWSwK, sygn. 6, k. 217-219. Stanisław Sobczak dla uwiarygodnienia własnej osoby oraz potwierdzenia przedstawionej wersji przyjechał do kancelarii z sołtysem i ławnikiem.

106 S. Zawadzki, Prawo Cywilne obowiqzujace $w$ Królestwie Polskim, t. 2, Warszawa 1861 , s. 865.

107 APP o/Konin, AnWSwK, sygn. 6, k. 279, 549-550. 
podziału gruntów, nie dając np. zgód na transakcje małymi działkami (1-2-morgowymi). Brak wprawdzie w kontraktach klauzul uniemożliwiających podział, ale także brak umów spisywanych przed notariuszem, a dotyczących obrotu częściami gospodarstw. Istnieje możliwość, że chłopi dokonywali takich transakcji prywatnie, z pominięciem kancelarii notarialnej ${ }^{108}$.

Celem dalszej analizy dokumentów notarialnych była próba odnalezienia umów dotyczacych nieruchomości o cechach własności pełnej lub do takiej się zbliżających. Przede wszystkim należało zwrócić uwagę na poluzowania zapisów kontraktów w zakresie konsensu, laudemium oraz powinności.

W przypadku dziesięciu umów z właścicielem zwierzchnim brak punktu mówiącego o konieczności uzyskania zgody dworu (lub prawa pierwokupu) na rozporządzanie zakupiona nieruchomością (np. kontrakt z 23 X 1809 r. $^{109}$ ).

Sytuacje takie nie były jednak jednoznaczne. Można przytoczyć przykłady pokazujace, że obracający następnie takim gruntem chłop nie przedstawiał do umowy sprzedaży konsensu (nie wymagano go w kancelarii $^{110}$, jak i sytuacje odwrotne ${ }^{111}$.

Wynikało to zapewne $\mathrm{z}$ hierarchii ważności zapisów w kontraktach z właścicielem zwierzchnim. Najdokładniej opisywano w nich powinności, monopole oraz laudemia, w tym kary grożące za niedopełnianie powyższych warunków, jako zagadnienia ściśle dotyczące kwestii ekonomicznych. Sprawę konsensu traktowano nieco swobodniej. Jak widać, mogło dochodzić nawet do pominięcia dotyczącego go zapisu, pomimo późniejszego wymagania od stron takiego dokumentu przy transakcji sprzedaży. Niewykluczone, że czasami traktowano konsens jako procedure uregulowaną zwyczajem, niejako oczywistą ${ }^{112}$.

Zwracaja także uwage dwa kontrakty dotyczące sprzedaży gruntów leżących na Olędrach Białobłockich w Puszczy Pyzdrskiej. W obydwu przypadkach kupującym był „uczciwy” Jan Hize z Adamowa koło Pyzdr. Zakupił on łącznie 16 mórg 15 prętów (zapewne miary chełmińskiej) wraz z budynkami ${ }^{113}$. Grunty i zabudowania sprzedali „uczciwy”

108 Transakcji takich często dokonywano na obszarze Królestwa Polskiego; H. Szymańska, dz. cyt., s. 84-86.

${ }^{109}$ APP o/Konin, SPPK, Scn, sygn. 74, k. 338-346.

110 APP o/Konin, AnWSwK, sygn. 10, k. 234-237.

111 APP o/Konin, AnWSwK, sygn. 13, k. 102-107.

112 W Królestwie Polskim zasad dotyczących konsensu nie uregulowano aż do 1858 r.; H. Szymańska, dz. cyt., s. 76.

${ }^{113}$ APP o/Konin, SPPK, Scn, sygn. 74, k. 102-106. 
Jan Meisner oraz szlachcic „urodzony” Józef Kleński, mieszkający na wspomnianych Olędrach. Obydwa kontrakty nie zawierały żadnych paragrafów mówiących o wymaganej zgodzie dworu, przypisanych do gospodarstw powinnościach, zapłacie laudemium, monopolach dworskich czy też wcześniejszych umowach będących podstawą użytkowania tychże gruntów.

Konstrukcja obu umów sugerowałaby, że mamy do czynienia z zakupem przez chłopa gruntów noszących charakter własności pełnej. Dodatkowo przemawiałby za tym fakt, że jednym ze sprzedajacych był szlachcic (nota bene niepiśmienny), czyli osoba, która w ówczesnych warunkach mogła taką własnością dysponować. Z drugiej strony wiadomo jednak, że drobna szlachta osiadła we wsiach olęderskich na terenie Puszczy Pyzdrskiej niejednokrotnie gospodarowała na gruntach, które użytkowała „prawem olenderskim”, czyli była zależna od dominium ${ }^{114}$. Trzeba też pamiętać, że dotychczasowe badania przyniosły bardzo nieliczne przykłady umów, dzięki którym chłopi w Księstwie Warszawskim byli właścicielami gruntów na zasadach pełnych ${ }^{115}$. Niewykluczone, że w powyższych kontraktach któryś z istotnych elementów, jak np. konsens, faktycznie nie był wymagany. Najprawdopodobniej jednak warunki mogace świadczyć o typie własności nie zostały po prostu do umowy wpisane z powodu zaniedbań urzędnika i transakcje te dotyczyły własności podległej.

Minister sprawiedliwości Księstwa rozporządzeniem z 15 V 1812 r. zalecał notariuszom, aby w każdym przypadku obrotu ziemia chłopska żądali konsensu oraz poświadczeń wpłaconego laudemium ${ }^{116}$. Można więc sądzić, że istniały $\mathrm{w}$ tym względzie liczne uchybienia. Ponadto wspomniane dwa kontrakty przyjął pisarz sądu pokoju zastępujący notariusza. Niewykluczone, że miał on gorsze przygotowanie lub mniej doświadczenia w czynnościach notarialnych, co zaskutkowało pewnymi niedociagnięciami.

Pozostałe 14 kontraktów, w których sprzedajacym grunt był chłop, a nie przedłożono konsensu i/lub poświadczenia opłaconego laudemium z powodu braku kontraktu z właścicielem zwierzchnim należy traktować

${ }_{114}$ Z. Chodyła, Zarys najstarszych dziejów osad olęderskich w Puszczy Pyzdrskiej 1746-1793, Pyzdry 2015, s. 113.

115 T. Mencel, Chłopska własność..., s. 60-63. Autor przytacza przykład 14 chłopów z Tuszowa w powiecie lubelskim, którym tamtejszy dziedzic Kajetan Hryniewicki podarował w 1808 r. „wiecznymi czasy” ok. 300 mórg gruntów oraz prawie 120 mórg lasu, równocześnie uwalniając ich od wszelkich powinności. Umowa ta w okresie Księstwa była respektowana.

116 Tamże, s. 82. 
najprawdopodobniej jako kolejne przykłady niestaranności sporządzających je urzędników.

Tylko dla jednej sprzedanej nieruchomości możemy mieć pewność, że zbliżała się w formie do własności pełnej. Chodzi o umowę pomiędzy „wielmożna” hrabiną Konstancją Mielżyńską a młynarzem Józefem Siewierskim z Morawina dotycząca sprzedaży młyna z gruntem (powierzchni nie znamy). Dwór w paragrafie 10 wyraźnie zrezygnował z prawa pierwokupu, a także pobierania laudemium, rezerwując dla siebie powinności w wymiarze rocznym, polegające na mieleniu dla dominium wyznaczonych ilości zboża oraz oddania 50 wierteli żyta ${ }^{117}$. Nie wymagano od kupujacego pańszczyzny. Prawa właściciela podległego względem zwierzchniego zostały $\mathrm{w}$ tym przypadku wyraźnie rozszerzone. Zatem zjawiska takie występowały, ale sporadycznie.

Podawane w kontraktach sumy, za które nabywano nieruchomości, dostarczają informacji o zasobach pieniężnych ludności chłopskiej. Precyzyjne dane dotyczące cen udało się ustalić dla 111 umów. W większości z nich (104) chłopi występowali jako kupujący, także od przedstawicieli własnego stanu. Na cenę danej nieruchomości mogły wpływać takie czynniki jak: stan budynków lub ich brak, obecność zasiewów i innych upraw, np. sadów, jakość i położenie gruntów oraz wysokość obciążeń dominialnych. W przypadku sprzedaży całych gospodarstw ceny podawane były zbiorczo, stąd nie da się określić wartości samych budynków. Transakcje, w których sprzedający należeli do szlachty, dotyczyły w większości tylko gruntów. Cena morgi chełmińskiej ustalona na ich podstawie kształtowała się najczęściej w przedziale 34-100 zł.

W około $2 / 3$ przypadków cała żądana kwota została wpłacona gotówką w dniu podpisania aktu. W przypadku pozostałych umów po uiszczeniu zadatku pozostała należność rozkładana była na różnej wielkości raty, których ostateczny termin płatności nie przekraczał 2 lat (najczęściej do roku).

Sytuacje, w których na sprzedającym gospodarstwie ciążyły jakieś długi, zdarzały się rzadko (10 przypadków). Tylko raz pojawia się informacja, że nabywcy na kupowany przez siebie grunt zaciagnęli kredyt ${ }^{118}$. Sytuacji takich mogło być jednak więcej. W badanym okresie poza dużymi ośrodkami funkcjonował jedynie trudniej uchwytny źródłowo kredyt pozainstytucjonalny.

W tabeli 3 została ukazana struktura wartości transakcji kupna-sprzedaży nieruchomości, w których co najmniej jedna stroną był chłop.

117 APP o/Konin, SPPK, Scn, sygn. 74, k. 58-65.

118 APP o/Konin, AnWSwK, sygn. 9, k. 346-347. 
Tabela 3. Struktura wartości transakcji kupna-sprzedaży nieruchomości, w których co najmniej jedną stroną był chłop, udokumentowanych przez notariat oraz sąd pokoju: Księstwo Warszawskie, powiat koniński, 1808-1815

\begin{tabular}{|l|c|c|c|c|}
\hline Wartość w zl & $\begin{array}{c}\text { Liczba } \\
\text { transakcji }\end{array}$ & $\begin{array}{c}\text { \% ogólnej } \\
\text { liczby } \\
\text { transakcji }\end{array}$ & $\begin{array}{c}\text { Wartość } \\
\text { transakcji } \\
\text { w zl }\end{array}$ & $\begin{array}{c}\text { \% ogólnej } \\
\text { wartości } \\
\text { transakcji }\end{array}$ \\
\hline $0-500$ & 32 & 29 & 8867 & 5,5 \\
\hline $501-1000$ & 39 & 35 & 27967 & 18 \\
\hline $1001-2000$ & 18 & 16 & 24991 & 16 \\
\hline$>2000$ & 22 & 20 & 95230 & 60,5 \\
\hline Razem & $\mathbf{1 1 1}$ & $\mathbf{1 0 0}$ & $\mathbf{1 5 7} \mathbf{0 5 5}$ & $\mathbf{1 0 0}$ \\
\hline
\end{tabular}

Źródło: APP o/Konin, AnWSwK, sygn. 3-10, 12-13; APP o/Konin, SPPK, Scn, sygn. 73-76.

Dane zaprezentowane w tabeli 3 pokazuja, że chłopi najczęściej zawierali kontrakty o wartości do 1000 zł (64\% wszystkich umów). Równocześnie ich wartość wynosiła tylko $23,5 \%$ całego badanego rynku nieruchomości chłopskich. Transakcje zaś o wartości najwyższej, powyżej $2000 \mathrm{zl}$, stanowiace jedynie $20 \%$ wszystkich, generowały aż $60 \%$ wartości obrotu. Średnia kwota transakcji w kontraktach z udziałem chłopów wynosiła $1415 \mathrm{zł}$. Wartość mediany została ustalona na poziomie 750 zł i jej wysokość należy uznać za reprezentatywną dla przeciętnej umowy z udziałem przedstawiciela stanu chłopskiego. Wydatkowane sumy mieściły się w szerokim przedziale: od 180 do $8700 \mathrm{zł}$.

Punktem odniesienia dla powyższych wartości mogą być ceny niektórych towarów i wysokość płac odnotowana dla okresu Księstwa Warszawskiego.

1) Ceny towarów:

- wiertel grochu (ok. $48 \mathrm{~kg})-6 \mathrm{zt}^{119}$,

- wiertel owsa (ok. $27 \mathrm{~kg}$ ) detal - $9 \mathrm{zt}^{120}$,

- wiertel żyta (ok. $39 \mathrm{~kg}$ ) detal - 9-11 zł ${ }^{121}$,

- wiertel żyta (ok. $39 \mathrm{~kg}$ ) hurt - $4 \mathrm{z}^{122}$,

- sążeń drewna (ok. 2,6 m³) - 9 zł $10 \mathrm{gr}^{123}$.

2) Gotówkowa część wypłat za pracę:

- roczne wynagrodzenie nauczyciela wiejskiego - $100 \mathrm{zl}^{124}$,

${ }^{119}$ AP w Poznaniu, Sąd Pokoju w Śremie, Wydział Sporny, sygn. 63, bpag. (sprawa nr 206).

120 Tamże, sygn. 11, k. 91.

121 Tamże, k. 3.

122 APP o/Konin, AnWSwK, sygn. 8, k. 53.

${ }^{123}$ AP w Poznaniu, Sąd Pokoju w Śremie, Wydział Sporny, sygn. 11, k. 136-137.

${ }^{124}$ Tamże, k. 160-160v. 
- roczne wynagrodzenie karbowego (około) - $100 \mathrm{zl}^{125}$,

- roczne wynagrodzenie parobka dworskiego - 108-120 zł ${ }^{126}$,

- roczny żołd szeregowca - 180-200 $\mathrm{zl}^{127}$,

- roczny żołd podoficera - 300-400 $\mathrm{zl}^{128}$.

3) Pensje roczne urzędników sądów pokoju, dane za rok 1810-1811 ${ }^{129}$ :

- woźny - $300 \mathrm{zl}$,

- burgrabia - $400 \mathrm{zl}$,

- podpisarz - $1600 \mathrm{zl}$,

- podsędek - $2000 \mathrm{zł}$.

Podajacc powyższe przykłady, trzeba brać pod uwagę trudności, jakie moga pojawić się podczas badań cen i płac w gospodarce przedkapitalistycznej. Należy pamiętać o często wysokim, a zarazem zróżnicowanym udziale naturaliów w wynagrodzeniach dla osób wykonujących różne, zwłaszcza proste prace. Ponadto cena danego towaru lub usługi dotyczyła tylko tej części, która przechodziła przez rynek. W okresie przedkapitalistycznym znaczna część dóbr w ogóle nie uczestniczyła w obrocie rynkowym, ponieważ gospodarka w znacznym stopniu była wciąż gospodarką naturalną. Dodatkowo w źródłach mogą występować tzw. dane nietypowe ${ }^{130}$. Dokonywane porównania moga więc mieć charakter jedynie orientacyjny.

Dla uzyskania kolejnego punktu odniesienia przeanalizowano ceny w 93 transakcjach z udziałem mieszczan. W większości przypadków, podobnie jak chłopi, występowali oni jako kupujący, głównie od przedstawicieli własnego stanu. Pozostałe dwie grupy społeczne nie zostały uwzględnione w porównaniu. Żydzi z uwagi na znacznie mniejszą liczbę umów, które podpisali (21), szlachta natomiast (71 umów) dlatego, że skala niektórych transakcji powodowała, iż są one w całości trudno porównywalne $\mathrm{z}$ działaniami dokonywanymi w tym zakresie przez pozostałe stany ${ }^{131}$.

125 J. Czubaty, dz. cyt., s. 331.

${ }^{126}$ Wysokość wynagrodzenia została ustalona przez prefekta poznańskiego 17 XI 1810 r.; T. Mencel, Pod zaborem pruskim i w Księstwie Warszawskim (1793-1814), w: Dzieje wsi wielkopolskiej, red. W. Rusiński, Poznań 1959, s. 128.

127 J. Czubaty, dz. cyt., s. 250.

128 Tamże.

129 A. Rosner, Sady pokoju w Księstwie Warszawskim, Warszawa 1985, mps pracy doktorskiej, Biblioteka Wydziału Prawa i Administracji Uniwersytetu Warszawskiego, s. 158.

${ }^{130}$ W. Kula, Problemy i metody historii gospodarczej, Warszawa 1983, s. 293-294, $544,570$.

131 Tylko jeden z kontraktów sprzedaży wsi zawarty pomiędzy szlachtą opiewał na kwotę 85 tys. zł; APP o/Konin, AnWSwK, sygn. 5, k. 612-614. Dla porównania suma wszystkich transakcji, w których uczestniczyli chłopi, wynosiła 157055 zł. 
W tabeli 4 została ukazana struktura wartości transakcji kupna-sprzedaży nieruchomości, w których co najmniej jedną stroną był mieszczanin.

Tabela 4. Struktura wartości transakcji kupna-sprzedaży nieruchomości, w których co najmniej jedna stroną był mieszczanin, udokumentowanych przez notariat oraz sąd pokoju: Księstwo Warszawskie, powiat koniński, 1808-1815

\begin{tabular}{|l|c|c|c|c|}
\hline Wartość w zl & $\begin{array}{c}\text { Liczba } \\
\text { transakcji }\end{array}$ & $\begin{array}{c}\text { \% ogólnej } \\
\text { liczby } \\
\text { transakcji }\end{array}$ & $\begin{array}{c}\text { Wartość } \\
\text { transakcji } \\
\text { w zl }\end{array}$ & $\begin{array}{c}\text { \% ogólnej } \\
\text { wartości } \\
\text { transakcji }\end{array}$ \\
\hline $0-500$ & 34 & 36,5 & 7084 & 6,5 \\
\hline $501-1000$ & 24 & 26 & 18137 & 16,5 \\
\hline $1001-2000$ & 19 & 20,5 & 27332 & 25,5 \\
\hline$>2000$ & 16 & 17 & 56492 & 51,5 \\
\hline Razem & $\mathbf{9 3}$ & $\mathbf{1 0 0}$ & $\mathbf{1 0 9} \mathbf{0 4 5}$ & $\mathbf{1 0 0}$ \\
\hline
\end{tabular}

Źródło: APP o/Konin, AnWSwK, sygn. 3-10, 12-13; APP o/Konin, SPPK, Scn, sygn. 73-76.

Struktura wartości powyższych umów była zbliżona do tych, w których co najmniej jedna stroną był chłop (tabela 3). Średnia kwota transakcji z udziałem mieszczan wynosiła 1170 zł. Wartość mediany została ustalona na poziomie 800 zł i jej wysokość należy uznać za przeciętna dla umowy z udziałem przedstawiciela stanu mieszczańskiego. Rozpiętość płaconych sum była większa niż w przypadku chłopów i zamykała się w przedziale od 30 do $10000 \mathrm{zł}$.

Grupa chłopów uczestnicząca w transakcjach była najprawdopodobniej reprezentatywna dla bogatszej warstwy stanu chłopskiego w badanym rejonie, czyli przede wszystkim dla włościan gospodarujących na podstawie lepszego prawa do ziemi oraz ewentualnie lepiej sytuowanych kmieci. Przypuszczalnie grupa ta stanowiła do 25\% ogółu stanu chłopskiego Wielkopolski ${ }^{132}$. W przypadku dokonujacych transakcji mieszczan trudno określić procentowo, jaką część swojego stanu reprezentowali. Prawdopodobnie nieco szerszą niż analizowani tu chłopi, ponieważ wartość dokonywanych przez nich transakcji wykazywała większą rozpiętość. Obracali zarówno bardzo małymi działkami, także na przedmieściach, jak i piętrowymi, murowanymi kamienicami położonymi przy rynkach Konina czy Koła.

Przytoczone dane moga wskazywać, że omawiana grupa chłopów prezentowała zbliżony poziom zamożności, mierzony wysokością kwot angażowanych w obrót nieruchomościami do porównywanej z nią części

${ }^{132}$ S. Borowski, Kształtowanie się rolniczego rynku pracy..., s. 48. 
ludności mieszczańskiej. W rękach tych ludzi znajdowały się niejednokrotnie wymierne ilości gotówki, kilku lub nawet kilkunastokrotnie przekraczające roczne wypłaty osób wykonujących podstawowe prace czy też niższych urzędników sądowych. Pozytywnie o płynności finansowej badanej tu grupy chłopów świadczy też niezbyt często stosowana przez nich forma płatności w ratach.

Jerzy Beniamin Flatt w swym opisie Księstwa Warszawskiego wskazywał, że na tle ogółu chłopów, znajdujących się w złej kondycji ekonomicznej, wyróżniała się grupa okupników ciesząca się zwykle dobra sytuacją materialna. Jak zaznaczał: „chłopi okupni mają się dobrze i jest wiele $\mathrm{w}$ niektórych miejscach, u których znaleźć można kilka tysięcy w gotowiźnie"133.

Warto też przyjrzeć się obszarom, na których osoby z poszczególnych stanów nabywały lub sprzedawały różne nieruchomości. Transakcje z udziałem chłopów niemal w 100\% dotyczyły gruntów bądź całych gospodarstw położonych na wsiach. Jedynie raz przedmiotem obrotu była nieruchomość miejska ${ }^{134}$. Tym samym analizowana dokumentacja nie pokazuje, aby chłopi dysponujacy gotówką lub możliwością zaciągnięcia kredytu inwestowali w domy bądź warsztaty pracy znajdujace się na terenach miejskich. Migracje ludności chłopskiej do miast, które w okresie Księstwa mogły nieco przybrać na sile z uwagi na zniesienie poddaństwa, dotyczyły raczej innych grup tego stanu. Zapewne były to osoby z rodzin biedniejszych, zasilające szeregi miejskich pracowników najemnych (w rzemiośle, handlu czy w rolnictwie). Grupa ta poprzez analizę akt notarialnych nie będzie uchwytna.

Podobnie rzecz miała się z pozostałymi stanami. Ich przedstawiciele dokonywali transakcji kupna-sprzedaży nieruchomości przede wszystkim w obrębie typowych dla siebie obszarów zamieszkania i działalności. W przypadku mieszczan jedynie $6 \%$ umów z ich udziałem dotyczyło gruntów na wsiach. Żydzi dokonywali transakcji wyłącznie nieruchomościami miejskimi. Szlachta sprzedawała głównie własność podległa chłopom oraz obracała pomiędzy sobą całymi wsiami lub ich częściami. Na 72 umowy z jej udziałem 11 (15\%) dotyczyło nieruchomości miejskich. Zostały one zawarte w większości przez szlachtę, która jako miejsce zamieszkania podała miasto. Przedstawione dane moga wskazywać, że ludność powiatu konińskiego na początku XIX w. wykazywała małą poziomą mobilność społeczna.

133 J.B. Flatt, Opis Księstwa Warszawskiego z krótkim rysem dziejów polskich aż do naszych czasów, Poznań 1809, s. 72, 74-75.

${ }^{134}$ APP o/Konin, AnWSwK, sygn. 8, k. 429-432. 
Z lektury zachowanych akt notarialnych wynika, że dotyczyły one chłopskiej gruntowej własności użytkowej położonej na terenach wiejskich (odnotowano tylko jeden przypadek sprzedaży przez chłopa nieruchomości miejskiej). Świadczyło to o niskiej poziomej mobilności społecznej tego stanu (podobnie jak i pozostałych) w badanym okresie. Własność ta obciążona była różnymi powinnościami oraz ograniczeniami, z których należy wymienić: czynsz (obciążenie główne), pańszczyznę (naliczana jedynie $\mathrm{w}$ wymiarze rocznym jako świadczenie dodatkowe), konieczność uzyskiwania zgody dworu na dysponowanie taką nieruchomościa oraz wymóg opłaty laudemium. Nie wszystkie te elementy musiały występować w każdym kontrakcie.

Równocześnie $\mathrm{z}$ analizowanego materiału wynika, że chłopi dysponowali w praktyce dużą swobodą obrotu własnościa podległa, a zgodę dworu na dokonanie transakcji, tzw. konsens, można w niektórych sytuacjach uznać za czystą formalność.

Przypadki sprzedaży chłopom własności zbliżającej się w swej formie do własności pełnej występowały, ale należy uznać je za sporadyczne. Można postawić hipotezę, że przyczyn takiego stanu rzeczy trzeba szukać nie w braku możliwości finansowych części chłopów wielkopolskich (te pozostawały na zadowalającym poziomie, co wynika z zaprezentowanej $\mathrm{w}$ artykule analizy), a raczej w braku woli przedstawicieli szlachty do zawierania z włościanami kontraktów na własność pełna, czyli nieobciążoną żadnymi ograniczeniami oraz powinnościami.

Przepisy Kodeksu Napoleona nie znalazły zastosowania w odniesieniu do analizowanych transakcji. Francuska kodyfikacja przeszczepiona na grunt Księstwa nie uznawała bowiem feudalnych form władania ziemia i zawierała przepisy (zwłaszcza art. 530), których celem było eliminowanie podobnych zjawisk z życia gospodarczego ${ }^{135}$. Można tym samym uznać, że Kodeks Napoleona pozostawał częściowo prawem martwym. Pokazuje to złożoność rzeczywistości ustrojowej Księstwa, na którego terenie funkcjonowały różne porządki prawne.

Chłopi aktywnie uczestniczyli w obrocie nieruchomościami na badanym obszarze, częściej sytuując się na pozycji kupujących niż sprzedających grunty, co wydaje się świadczyć, że dostrzegali zasadność takich

${ }^{135}$ Kodeks Napoleona zrywał z koncepcją własności podzielonej, gdyż prawo właściciela zwierzchniego zostało potraktowane jako rodzaj wierzytelności, a nie jako własność. Równocześnie ustanawiał w art. 530 możliwość wykupienia rent wieczystych. Miało to na celu niedopuszczenie do utrzymywania się w tej formie zależności feudalnej; W. Sobociński, dz. cyt., s. 216, 219. 
inwestycji. Obok mieszczan był to stan najczęściej dokonujący transakcji kupna-sprzedaży nieruchomości

Wysokość środków finansowych angażowanych przez chłopów w inwestycje w grunty sytuowała ich na podobnym poziomie zamożności jak dokonujących obrotu nieruchomościami mieszczan, potwierdzając tym samym niektóre opinie z epoki mówiące o występowaniu na terytorium Księstwa względnie zamożnej grupy chłopów okupnych.

Szersza ocena powyższych zjawisk wymaga porównania ich z sytuacja panującą w pozostałych rejonach Księstwa. W chwili obecnej nie jest to możliwe z uwagi na brak podobnych studiów. Wydaje się więc zasadne przeprowadzenie dalszych tego typu badań, zarówno dla innych obszarów, jak i okresów (Królestwo Polskie przed uwłaszczeniem 1815-1864).

\section{Bibliografia}

\section{Źródła archiwalne}

Archiwum Państwowe w Poznaniu

Sąd Pokoju w Śremie, Wydział Sporny, sygn. 11, 63.

\section{Archiwum Państwowe w Poznaniu Odział w Koninie}

Akta notariusza Wilhelma Sztandke w Koninie, sygn. 3, 4, 5, 6, 7, 8, 9, 10, 12,13

Sąd Pokoju Powiatu Konińskiego, Sprawy cywilne niesporne, sygn. 73, 74, $75,76$.

Archiwum Państwowe w Warszawie Oddział w Grodzisku Mazowieckim Kancelaria Paciorkowskiego Karola notariusza w Błoniu, sygn. 1.

\section{Biblioteka Kórnicka}

Rękopisy, sygn. BK 02702, BK 02705, BK 02709.

\section{Źródła drukowane}

Dziennik Praw Księstwa Warszawskiego, t. 1, Warszawa 1810.

Flatt J.B., Opis Księstwa Warszawskiego z krótkim rysem dziejów polskich aż do naszych czasów, Poznań 1809.

Ksiegga tawnicza wsi Kargowej w powiecie kościańskim 1617-1837, wyd. A. i A. Walawenderowie, Warszawa 1960 (Studia z Dziejów Gospodarstwa Wiejskiego, 3).

Powszechne Prawo Kraiowe dla Państw Pruskich, cz. 1, t. 2, cz. 2, t. 1, Poznań 1826. 


\section{Opracowania}

Borowski S., Ksztattowanie się rolniczego rynku pracy $w$ Wielkopolsce $w$ okresie wielkich reform agrarnych 1807-1860, Poznań 1963.

Borowski S., Rozwarstwienie wsi wielkopolskiej w latach 1807-1914. Studium statystyczne nad społecznymi i ekonomicznymi nastepstwami wtaczenia wsi w orbite rynku, Poznań 1962.

Chodyła Z., Zarys najstarszych dziejów osad olęderskich w Puszczy Pyzdrskiej 1746-1793, Pyzdry 2015.

Czubaty J., Księstwo Warszawskie (1807-1815), Warszawa 2011.

Dworzaczek W., Przenikanie szlachty do stanu mieszczańskiego $w$ Wielkopolsce $w$ XVI $i$ XVII $w .$, PH, t. 47, 1956, nr 4, s. 656-684.

Filipiak Z., Projekt urzadzenia ogólnego ludności żydowskiej w Księstwie Warszawskim z 1809 r., CPH, t. 68, 2016, nr 2, s. 147-166.

Gloger Z., Encyklopedia staropolska, t. 2, 4, Warszawa 1972.

Grabski W., Historya Towarzystwa Rolniczego 1858-1861 r., t. 1, Warszawa 1904.

Grochulska B., Księstwo Warszawskie, Warszawa 1966.

Grynwaser H., Kwestia agrarna i ruch włościan w Królestwie Polskim w pierwszej połowie XIX wieku, w: tenże, Pisma, t. 2, Wrocław 1951, s. 1-209.

Ihnatowicz I., Biernat A., Vademecum do badań nad historia XIX $i$ XX wieku, Warszawa 2003.

Kamler M., Przemoc między szlachta $w$ Polsce $w$ XVII w. - zjawisko masowe?, KH, t. 121, 2014, nr 3, s. 541-569.

Kazimierski J., Akta notarialne $i$ ich znaczenie dla badań historycznych $X I X$ w., St. Źródł., t. 4, 1959, s. 109-124.

Kędelski M., Ludność powiatu konińskiego na przełomie XVIII i XIX wieku, „Rocznik Koniński” 11, 1997, s. 25-53.

Kubicki T., Ustalanie tożsamości stron $w$ świetle obowiazujacych na ziemiach Królestwa Polskiego $w$ XIX wieku przepisów notarialnych $i$ hipotecznych a praktyka, „Studia z Dziejów Państwa i Prawa Polskiego” 15, 2012, s. 97-105.

Kula W., Problemy i metody historii gospodarczej, Warszawa 1983.

Leśnodorski B., Elementy feudalne i burżuazyjne $w$ ustroju i prawie Księstwa Warszawskiego, CPH, t. 3, 1951, s. 304-332.

Łukasiewicz D., Uwagi o położeniu chłopów pod zaborem pruskim (Prusy Południowe i Zachodnie) $w$ końcu XVIII i na poczatku XIX w., PH, t. 103, 2012, nr 2, s. 303-331.

Mazurkiewicz J., Znaczenie akt notarialnych dla badań nad wtasnościa $w$ Księstwie Warszawskim i Królestwie Polskim, „Annales Universitatis Mariae Curie-Skłodowska. Sectio F, Nauki Filozoficzne i Humanistyczne” 20, 1965, nr 7, s. 115-126.

Mencel T., Chłopi w wyborach do sejmu Księstwa Warszawskiego, w: Wiek XIX. Prace ofiarowane Stefanowi Kieniewiczowi $w$ 60. rocznice urodzin, red. B. Grochulska, B. Leśnodorski, A. Zahorski, Warszawa 1967, s. 109-124.

Mencel T., Chłopska własność i posiadanie ziemi przed uwłaszczeniem $w$ Królestwie Polskim, RDSG, t. 48, 1987, s. 53-77. 
Mencel T., Pod zaborem pruskim $i$ w Księstwie Warszawskim (1793-1814), w: Dzieje wsi wielkopolskiej, red. W. Rusiński, Poznań 1959, s. 115-140.

Mencel T., Zniesienie poddaństwa $w$ Księstwie Warszawskim na tle porównawczym, „Acta Universitatis Lodziensis. Folia Historica” 13, 1983, s. 6-41.

Opaliński T., Stan chłopski w Księstwie Warszawskim w świetle akt sadowych, Warszawa 2018, mps pracy magisterskiej, Archiwum Prac Dyplomowych Uniwersytetu Kardynała Stefana Wyszyńskiego.

Orłowski R., Oczynszowanie włościan w dobrach Andrzeja Zamoyskiego, „Annales Universitatis Mariae Curie-Skłodowska. Sectio H, Oeconomia” 1, 1967, s. $119-140$.

Radwański Z., Wassicki J., Najważniejsze zmiany w polskim prawie cywilnym $w$ okresie oświecenia, CPH, t. 4, 1952, s. 37-93.

Rosner A., Sady pokoju w Księstwie Warszawskim, Warszawa 1985, mps pracy doktorskiej, Biblioteka Wydziału Prawa i Administracji Uniwersytetu Warszawskiego.

Rusiński W., Osady tzw. „Olędrów”w dawnym woj. poznańskim, Kraków 1947. Rutkowski J., Poddaństwo wtościan $w$ XVIII wieku w Polsce $i$ niektórych innych krajach Europy, w: tenże, Wieś europejska późnego feudalizmu (XVI-XVIII w.), Warszawa 1986, s. 25-215.

Stownik języka polskiego, t. 4, 6, red. A. Kryński, W. Niedźwiedzki, Warszawa 1952.

Sobociński W., Historia ustroju i prawa Księstwa Warszawskiego, Toruń 1964 (Roczniki Towarzystwa Naukowego w Toruniu, 70, 1).

Stankiewicz Z., Szlachta wobec zniesienia poddaństwa w Księstwie Warszawskim, „Acta Universitatis Lodziensis. Folia Historica” 13, 1983, s. 43-71.

Szymańska H., Niektóre problemy chłopskich praw do ziemi w Królestwie Polskim w latach 1815-1864, CPH, t. 13, nr 1, 1961, s. 57-97.

Szymańska H., Śmiałowski J., Akta notarialne z terenu Królestwa Polskiego $i$ ich wartość naukowa, „Archeion” 30, 1959, s. 43-67.

Topolski J., Uwagi o strukturze gospodarczo-społecznej Wielkopolski w XVIII wieku, czyli dlaczego na jej terenie nie byto żydowskich karczmarzy, w: Żydzi w Wielkopolsce na przestrzeni dziejów, red. J. Topolski, K. Modelski, Poznań 1999, s. 71-82.

Wietrzychowski B., O finansach komunalnych miasta Poznania roku 1780 i współczesnych (studium porównawcze), „Kronika Miasta Poznania” 15, 1937, nr 3, s. 254-284.

Więcławski B., Zarys problematyki miar powierzchni gruntów oraz produkcji zbożowej we wsiach miasta Poznania $w$ XVIII wieku, „Studia i Materiały do Dziejów Wielkopolski i Pomorza” 15, 1983, nr 1, s. 39-61.

Wiśniewska-Jóźwiak D., Dzierżawa wieczysta $i$ emfiteuza $w$ polskim prawie przedrozbiorowym, „Przegląd Nauk Historycznych” 13, 2014, nr 2, s. 133-145.

Wójcikiewicz W., Prawo hipoteczne Królestwa Polskiego, Wrocław-Warszawa-Kraków 1967.

Zawadzki S., Prawo Cywilne obowiqzujace w Królestwie Polskim, t. 2, Warszawa 1861. 
Tomasz Opaliński

Peasant right to land and participation of peasants in property trade in the Duchy of Warsaw through the lens of notarial deeds

(on the example of Konin County)

(Summary)

Despite the adoption of the Napoleonic Code in the Duchy of Warsaw, the local nobility continued to conclude purchase/sale agreements with peasants, the result of which was divided dominium, a feudal form of land property. The noble also continued to trade in such estates.

The article contains an analysis of notarial deeds of property sale/purchase in which at least one of the parties was a peasant and which were drawn up in the area of the Konin Country during the existence of the Duchy of Warsaw (1808-mid-1815). All but one concerned trade in properties located in rural areas. When analysing agreements in which the seller was a nobleman, emphasis was put on the scope of liabilities imposed on peasants (quit rent, serfdom) or of any other conditions, such as the need to obtain the court's permit to manage the property (consensus) or the requirement to pay a laudemium amounting to $10 \%$ of the transaction value at the purchase. In case of agreements concluded between subordinate owners, the key aspect was the practical scope of the aforementioned restrictions.

It is still necessary to shed more light on the issue of the management of full property rights or adjacent forms of ownership by peasants in the discussed period. The present publication seeks to fill in some of the gaps in the knowledge on this particular issue.

The analysis of the sums paid out and received by peasants in the researched transactions has provided new data on the financial resources of peasantry in the pre-enfranchisement period.

The analysis also comprises the issue of the participation of peasants in the property trade compared to other social classes.

Tomasz Opaliński - doktorant w Akademii Humanistycznej im. Aleksandra Gieysztora w Pułtusku (Wydział Historyczny). Zainteresowania badawcze: historia chłopów polskich w XIX-XX w., ze szczególnym uwzględnieniem aspektów społecznych i gospodarczych.

Tomasz Opaliński - doctoral student at the Faculty of History, Aleksander Gieysztor Academy of Humanities in Pułtusk. Research interests: history of Polish peasants in the nineteenth-twentieth century with emphasis on the social and economic aspects.

E-mail: skito69@o2.pl. 